\title{
Barriers of solar energy uptake and the potential for mitigation solutions in Barbados
}

Article

Accepted Version

Creative Commons: Attribution-Noncommercial-No Derivative Works 4.0

Wyllie, J. O. Y., Essah, E. and Ofetotse, E. (2018) Barriers of solar energy uptake and the potential for mitigation solutions in Barbados. Renewable and Sustainable Energy Reviews, 91. pp. 935-949. ISSN 1364-0321 doi:

https://doi.org/10.1016/j.rser.2018.04.100 Available at https://centaur.reading.ac.uk/76649/

It is advisable to refer to the publisher's version if you intend to cite from the work. See Guidance on citing.

To link to this article DOI: http://dx.doi.org/10.1016/j.rser.2018.04.100

Publisher: Elsevier

All outputs in CentAUR are protected by Intellectual Property Rights law, including copyright law. Copyright and IPR is retained by the creators or other copyright holders. Terms and conditions for use of this material are defined in the End User Agreement.

www.reading.ac.uk/centaur 
Central Archive at the University of Reading

Reading's research outputs online 


\title{
Barriers of solar energy uptake and the potential for mitigation solutions in Barbados
}

\author{
Jamalia O. Y. Wyllie ${ }^{1}$, Emmanuel A Essah ${ }^{1^{*}}$ and Eng L. Ofetotse ${ }^{1}$ \\ ${ }^{1}$ Construction Management and Engineering, School of the Built Environment, University of \\ Reading, Reading, RG6 6AW \\ *corresponding author: e.a.essah@ reading.ac.uk
}

\begin{abstract}
Understanding the barriers that inhibit the deployment of renewable energy technologies to achieve long-term reductions in carbon emissions from the use of fossil fuels is paramount to Barbados. Although there are targets towards renewable energy (solar, wind, biomass, geothermal) uptake, the share of these technologies in the energy mix does not exist in Barbados due to the total dependence on fossil fuels. In this paper, a review of potential challenges and the main problems for deployment of alternative energy sources is presented. Through interviews, questionnaires with a focus group of key personnel's, the paper documents the lack of renewable energy sources (with emphasis on solar energy) as one of the main alternatives to meet the carbon emission targets set by the country. The barriers and challenges facing the implementation of solar energy deployment have been clarified. From the results, it is evident that significant policy barriers still exist at the country level, which has reduced the effectiveness of a concerted national effort to deploy renewables. The current policy landscape which benefits from fossil fuel imports, the lack of technical know-how and the lack of research and development in the renewable energy space are amongst the key barriers identified. The paper also outlines the key policy's frameworks, regulatory environment and the lack of incentives, which encompasses the renewable energy sector, and presents a critical analysis of the barriers faced by the industry. A mitigation framework is proposed to bridge the gap of solar energy (renewable energy) deployment.
\end{abstract}

Keywords:

Barbados, renewable energy, solar energy, barriers, mitigation solutions

\section{Introduction}

In 2015, fossil fuels were the main form of global conventional energy with the consumption of 13,147.3 million tonnes oil equivalent [1]. The fact remains that energy usage increases as the world population increases, which now stands at 7.5 billion and is expected to reach 8.5 billion by 2030 [2,3]. Economic activities, progressive communication, transportation, and improved quality of life have also contributed to the global energy demand increase $[4,5]$.

Barbados, a small island developing state (SIDS) in the Caribbean, is considered a socially and economically developed country, with a human development index of 0.795 and a gross domestic product (GDP) per capita of USD 16.425 [6]. This $460 \mathrm{~km}^{2}$ island has a population of 291,495 equating to a population density of 668.6 per $\mathrm{km}^{2}$, making it the $15^{\text {th }}$ most densely 
populated country in the world $[7,8]$. The average daily energy demand for the population, electricity generation and transportation for Barbados is 11,297 barrels of oil per day (BOPD) [9]. Unfortunately, Barbados' fossil fuel reserves only produce approximately 500 BOPD to 1000 BOPD equivalent of natural gas [10]. To account for the shortfall from the reserves, Barbados is heavily reliant on imports, such as heavy fuel oil, jet oil and diesel, costing the country \$452 million Barbados dollars (BDS) (USD 226 million ) in 2015 [11].

Continued reliance on imported fossil fuel increases Barbados' vulnerability to fluctuating international oil prices [12] and the combustion of fossil fuels releases harmful greenhouse gases (GHG), contributing to climate change [13,14]. However, decreasing expenditure on fossil fuel is paramount to the Government of Barbados (GOB), due to the difficult economic conditions such as a high fiscal deficit of $\$ 583.6$ million BDS [15].

To lessen fossil fuel dependence and curb the effects of climate change, the GOB has produced draft policies and frameworks to promote renewable energy technologies, as an alternative to fossil fuels [16]. Globally, there has been a paradigm shift to the use of renewable energy as an alternative fuel, due to the fact that it is environmentally friendly. Renewable energy accounted for $2.8 \%$ of global energy consumption [17] and supplied $23.7 \%$ of global electricity in 2015 [18]. Renewable energy (RE) capacity is expected to grow with enhanced financing and low prices for long-term contracts $[18,19]$.

As with most countries, Barbados has set targets for energy efficiency through the implementation of renewable energy sources. Renewable energy is targeted to contribute to $65 \%$ of total peak electricity demand by 2030 and electrical energy efficiency is to be achieved by a $22 \%$ reduction in electrical consumption compared to a 'business-as-usual' scenario by 2029 [20]. It is estimated that accomplishing these targets would save the country more than USD 283.5 million in electricity costs [20,21]. It must be noted however that, considering all the $\mathrm{RE}$ resources in Barbados, solar energy is the most viable source (average solar irradiance of $5.4 \mathrm{kWh} / \mathrm{m}^{2} /$ day), hence considered as the main RE source to achieve these targets [22].

Solar energy uptake in Barbados has been restricted by barriers, some of which were first identified in the Sustainable Energy Framework for Barbados, conducted by the InterAmerican Development Bank (IDB) and the Government in 2010 [21]. The barriers identified for solar water heaters $(\mathrm{SWH})$, solar photovoltaics and hybrid photovoltaics/thermal were: limited access to capital, incomplete information, lack of policies governing the injection of renewable energy resources into the grid and economic regulatory distortion [21]. Focused on SWH systems, Rogers [22], identified lack of incentives, information and innovation as some of the barriers hindering further market penetration. However, to date, the barriers relating to the uptake of other solar energy resources have not been investigated.

In this regard, if Barbados aims to reduce Government expenditure and its dependence on fossil fuels, renewable energy uptake must increase. As a result, the lack of data implies that the use of solar energy and the barriers inhibiting uptake need to be mitigated with urgency. There is the need to identify present barriers for mitigation, but there has been no information from studies which adequately covers the barriers of solar photovoltaics, SWH systems and concentrated solar technologies. In the light of this, this paper presents investigation relating to the barriers that inhibit the expansion of the uptake of solar energy technologies in Barbados as well as identifying potential mitigation solutions. 
To develop the background context, the paper introduces Small Island Developing States (SIDS), the Caribbean and their energy challenges in the next section.

\section{Small Island Developing States and the Caribbean}

In 1992, the United Nations Conference on Environment and Development (UNCED) identified a divergent group of developing countries facing specific social, economic and environmental vulnerabilities known as Small Island Developing States (SIDS) [14]. SIDS represent fifty-two countries and territories over three geographical regions: the Caribbean, the Pacific and the Atlantic, Indian Ocean, Mediterranean and South China Sea (AIMS) (See Figure 1). SIDS are developmentally disadvantaged and require special support from the international community due to the following challenges [23]:

1. Narrow resource base depriving them of the benefits of economies of scale;

2. Small domestic markets and heavy dependence on external and remote markets;

3. High costs for energy, infrastructure, transportation, communication and servicing;

4. Long distances from export markets and import resources;

5. Fragile natural environments and little resilience to natural disasters;

6. Growing population;

7. High volatility of economic growth;

8. Limited opportunities for the private sector and heavy reliance on the public sector.

In the context of this research, only SIDS within the Caribbean region is discussed further.

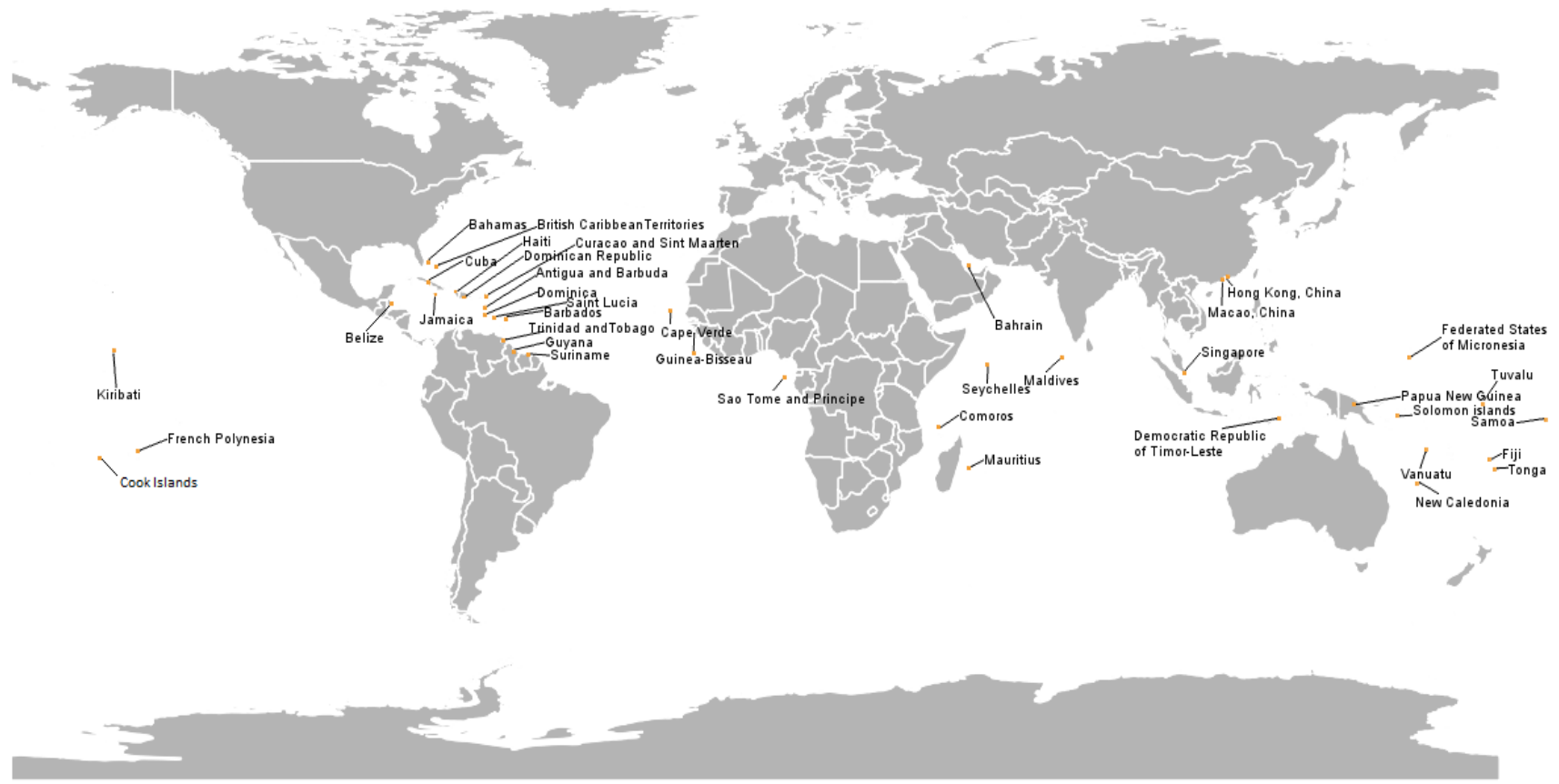

Figure 1: Map of Small Island Developing States. Source: [24]

The seven challenges highlighted previously represent the challenges of all SIDS, irrespective of geographical location. However, challenges 3, 5 and 7 are specific to Caribbean SIDS. Energy security concerns are increasing for Caribbean SIDS due to the volatile cost of fossil 
fuels. In addition, fossil fuel procurement activities are now increasingly more technically difficult, causing continuously interrupted availability [25,26].

Energy security concerns are especially daunting for Caribbean SIDS as the archipelago is highly dependent on imported fossil fuels, which represents $87 \%$ of the primary energy consumed [27,28]. Imported petroleum products are predominantly used for transport and electricity generation and the latter costs the Caribbean USD 4 billion in energy expenditure, as the generation of electricity from petroleum is significantly more expensive than other fuels [28]. High electricity generation costs associated with petroleum as the feedstock has resulted in the Caribbean having the most expensive retail electricity rates in the world, with an average of $\$ 0.35$ per kilowatt hour $(\mathrm{kWh})$ compared to countries such as the USA with $\$ 0.12 / \mathrm{kWh}$ $[12,28]$. Trinidad and Tobago however, does not conform to these high electricity rates since their energy source is mainly natural gas; a cheaper fuel source [29].

Governments of Caribbean SIDS are committed to the urgent action required to decrease fossil fuel dependence, as it requires significant national expenditure, which stifles economic growth and diverts financial resources from health, education and developmental activities [26]. The fragile ecosystems in Caribbean SIDS are also vulnerable to climate change and global warming impacts caused by a direct result of carbon dioxide $\left(\mathrm{CO}_{2}\right)$ emissions from the combustion of fossil fuels [30,31]. These impacts include intensified natural disasters, damage to ecosystems and sea-level rise, which threatens coastal-concentrated agricultural land and infrastructure, [32,33,34].

For unification and a voice in the international arena, twenty of the twenty-eight countries in the Caribbean are members of the Caribbean Community Market (CARICOM). CARICOM is tasked with the promotion of economic integration, human and social development, security and policy co-ordination [35]. The CARICOM Energy Policy was initiated in 2013, as a regional programme to [36]:

- Diversify energy sources;

- Increase energy efficiency;

- Accelerate the deployment of renewable and clean energy;

- Increase installed renewable energy capacity in member states.

The policy set short-term (2017), medium term (2022) and long-term (2027) regional sustainable energy targets for renewable energy, efficiency and reductions in $\mathrm{CO}_{2}$ (Table 1).

Table 1: Regional Sustainable Energy Targets for CARICOM countries.

\begin{tabular}{lccc}
\hline & $\mathbf{2 0 1 7}$ & $\mathbf{2 0 2 2}$ & $\mathbf{2 0 2 7}$ \\
\hline Regional Sustainable Energy Targets & \multicolumn{3}{c}{} \\
\hline Renewable energy power capacity & 20 & 28 & 47 \\
Reduction in energy intensity & - & - & 33 \\
Reduction in power sector $\mathrm{CO}_{2}$ emissions & 18 & 32 & 36 \\
\hline Source: $[16]$.
\end{tabular}

To meet these targets set by CARICOM, as of 2015, the installed renewable energy capacity in CARICOM countries have increased steadily in some countries compared to others. A summary of the installed capacities is illustrated in Table 2. 
Table 2: Installed power capacity and share of renewable energy capacity in CARICOM countries.

\begin{tabular}{|c|c|c|c|}
\hline Country & $\begin{array}{c}\text { Installed renewable } \\
\text { energy power } \\
\text { capacity }\end{array}$ & $\begin{array}{c}\text { Renewable energy } \\
\text { share of installed } \\
\text { power capacity }\end{array}$ & $\begin{array}{l}\text { Total installed } \\
\text { power capacity }\end{array}$ \\
\hline & MW & percent & MW \\
\hline Belize & 82.5 & 58.2 & 141.8 \\
\hline Suriname & 189.0 & 46.1 & 410.0 \\
\hline Dominica & 7.6 & 28.6 & 27.7 \\
\hline Haiti & 62.4 & 16.0 & 390.0 \\
\hline Guyana & 55.1 & 14.4 & 383.0 \\
\hline St Vincent and the Grenadines & 6.4 & 12.2 & 52.3 \\
\hline Jamaica & 72.0 & 7.8 & 926.4 \\
\hline St. Kitts and Nevis & 3.2 & 5.7 & 56.4 \\
\hline Barbados & 5.5 & 2.3 & 240.0 \\
\hline Grenada & 0.7 & 1.4 & 48.6 \\
\hline Antigua and Barbuda & 0.8 & 0.7 & 113.0 \\
\hline Saint Lucia & 0.2 & 0.2 & 88.6 \\
\hline Trinidad and Tobago & 0.01 & 0.005 & 2368.0 \\
\hline The Bahamas & 0.0 & 0.0 & 536.0 \\
\hline Montserrat & 0.0 & 0.0 & 5.5 \\
\hline
\end{tabular}

Source: [16].

From Table 2, Belize's and Suriname's renewable energy shares of installed power capacity are well above the 2027 target with $58.2 \%$ and $46.1 \%$ respectively, while Dominica is above the 2022 target by $0.6 \%$. The remaining CARICOM countries exhibit significant and largely unexploited development of renewable energy sources, of which solar and wind are abundant, but remain severely underutilised [16].

Barbados has $2.3 \%$ of renewable energy contributing to its $240 \mathrm{MW}$ power capacity [16]. The succeeding sections delve into Barbados' energy sector, policies and commitments, the uptake of renewable energy (solar energy) and challenges.

\section{Current state of knowledge in Barbados}

\subsection{Energy landscape}

Domestic oil and natural gas reserves supply 14\% of Barbados' energy demand and imported fossil fuels account for $86 \%$ [37]. Barbados' energy mix is dominated by heavy fuel oil $(37 \%)$, diesel (18\%) and gasoline (17\%) [9], used primarily for electricity generation and transportation.

The Division of Energy, a Governmental body, also tasked with monitoring the movement of petroleum price movements and domestic and regional energy issues to name a few [38], spearheaded the optimum function of the energy sector. The Barbados Light and Power Company (BL\&P) exclusively supplies electricity, a privately owned, vertically integrated utility, responsible for generation, transmission and distribution [39]. The BL\&P has a total installed generating capacity of 239.1 MW, servicing 125,991 customers [40]. 


\subsection{Economic landscape}

In 2008, the economy was severely affected by the global financial crisis, which crippled the tourism, construction, international banking and financing sector [41]. With a GDP per capita of USD 16,425, Barbados has a gross debt-to-GDP estimated at 105\% and foreign reserves are $\$ 705.4$ million BDS or 10.7 weeks. [6,15]. The debt currently held by the Central Bank of Barbados is $\$ 1,895.1$ million BDS and the country has received several negative credit rating downgrades over the last decade with the most recent rating stating that the economy has a negative outlook and is in default with little prospect for recovery [41].

Any form of Government revenue is of the utmost importance, due to the state of the economy. Revenue is acquired from taxes (value-added-tax and excise tax) applied to the purchase of electricity, gasoline and diesel. An estimated \$400 million BDS in revenue is received through energy taxation to pay Government wages and salaries [15,42].

To avoid defaulting and to reduce the fiscal deficit, severe measures, which were first introduced as temporary but have since been instituted indefinitely. One such tax is the National Social Responsibility Levy (NSRL), a 2\% levy on all imports to the island (excluding manufacturing, agricultural and tourism sectors) and increased excise tax on gasoline and diesel [43].

\subsection{Policies and frameworks}

The Government of Barbados (GoB) has developed policies and frameworks to address fossil fuel usage, renewable energy uptake and the impact of climate change [20,44]. Table 3 presents a summary of the policies and frameworks, how it has evolved over the years and potential aspirations/goals to achieve the set target. 
Table 3: Policies and frameworks instituted by the Government of Barbados.

Policy/ Framework

Year

Key points

Targets

Reference

The Draft National Energy Policy of Barbados

2006

Lack of diversification in the energy mix; lessening the dependence of fossil fuels by increasing energy efficiency and renewable energy, at all stages of consumption. (The policy was never formally adopted but plays a fundamental role in the energy landscape).

Assessed the economic viability of renewable energy technologies; identified barriers and recommendations for the implementation of energy

The Sustainable Energy Framework for Barbados efficiency projects; reduce energy costs, improve energy security and enhance environmental sustainability and decrease dependence on fossil fuels

Climate action plan for the reduction of greenhouse gas, in accordance with the UNFCCC, in advance of the Paris Agreement.

The Intended Nationally Determined Contribution

Currently in development to provide clear direction (short, medium and long-term) for the GoB, with respect to production, consumption and the

The Interim Draft of National Energy Policy for Barbados development of renewable and non-renewable energies. This new policy promotes economic and environmental sustainability and builds on policies and frameworks above.
$10 \%$ national energy usage from renewable sources by 2012 and a further $20 \%$ by 2026

Renewable energy would account for $29 \%$ of electricity consumption from renewable energy by 2029; an overall 22 $\%$ reduction in electricity consumption from energy efficiency technologies compared to a 'business as usual' scenario by 2029 .

Increased the existing renewable energy target from $29 \%$ by 2029 to $65 \%$ renewable energy contributing

to the total peak electricity demand by 2030 .

A $75 \%$ reduction in total fossi fuel consumption to be substituted by natural gas and

renewable energy sources. 
To date, the regulatory frameworks and policies for RE update in Barbados incorporate net metering/billing; labelling standards (for energy efficiency), tax credits; tax reductions/ exemptions, public loans/grants and interconnection standards [39]. The Electric Light and Power Act (ELPA) of 2013 allows the distribution of energy generated from the interconnection standards authorises independent power producers (IPPs). IPPs produces distribution is via solar and wind energy sources to operate and compete against the utility and exempts residential and non-residential renewable technologies from licensing agreements once they did not exceed $5 \mathrm{~kW}$ and $50 \mathrm{~kW}$ respectively [39].

\subsection{Solar Energy Generation}

Barbados has a long history of using renewable energy sources such as wind and solar. Windmills were used to grind sugar for the once prolific sugar industry, and solar drying was traditionally used for the preservation agricultural crops. Solar dryers, solar distillation stills and SWHs have been utilised on the island since the late 1960's and are still in use today [46].

The production of electricity from solar energy technologies (including solar coolers, ice makers, lighting systems and installations for public demonstrations) was first initiated and financed by the GoB in 2000 [47]. Unfortunately, installations stalled thereafter due to inadequate market analysis and high initial costs [48]. Installations were reinstituted after the institution of the Renewable Energy Rider (RER) tariff programme by the BL\&P in 2010. The RER grants allowance to customers to generate electricity with a temporary feed-in-tariff (FiT) of $\$ 0.416 / \mathrm{kWh}$ for solar photovoltaics and $\$ 0.3015 / \mathrm{kWh}$ for wind energy $[9,39]$.

The growth of the RER tariff programme represented in Figure 2 is predominately due to solar photovoltaics installed capacity of $12.9 \mathrm{MW}$ from both residential and commercial customers. Barbados' first 10MW solar farm was commissioned in 2016 and the total solar energy capacity of Barbados is approximately $22.9 \mathrm{MW}[16,49]$. It is unclear whether the 10MW solar farm input is included in the RER growth plot.

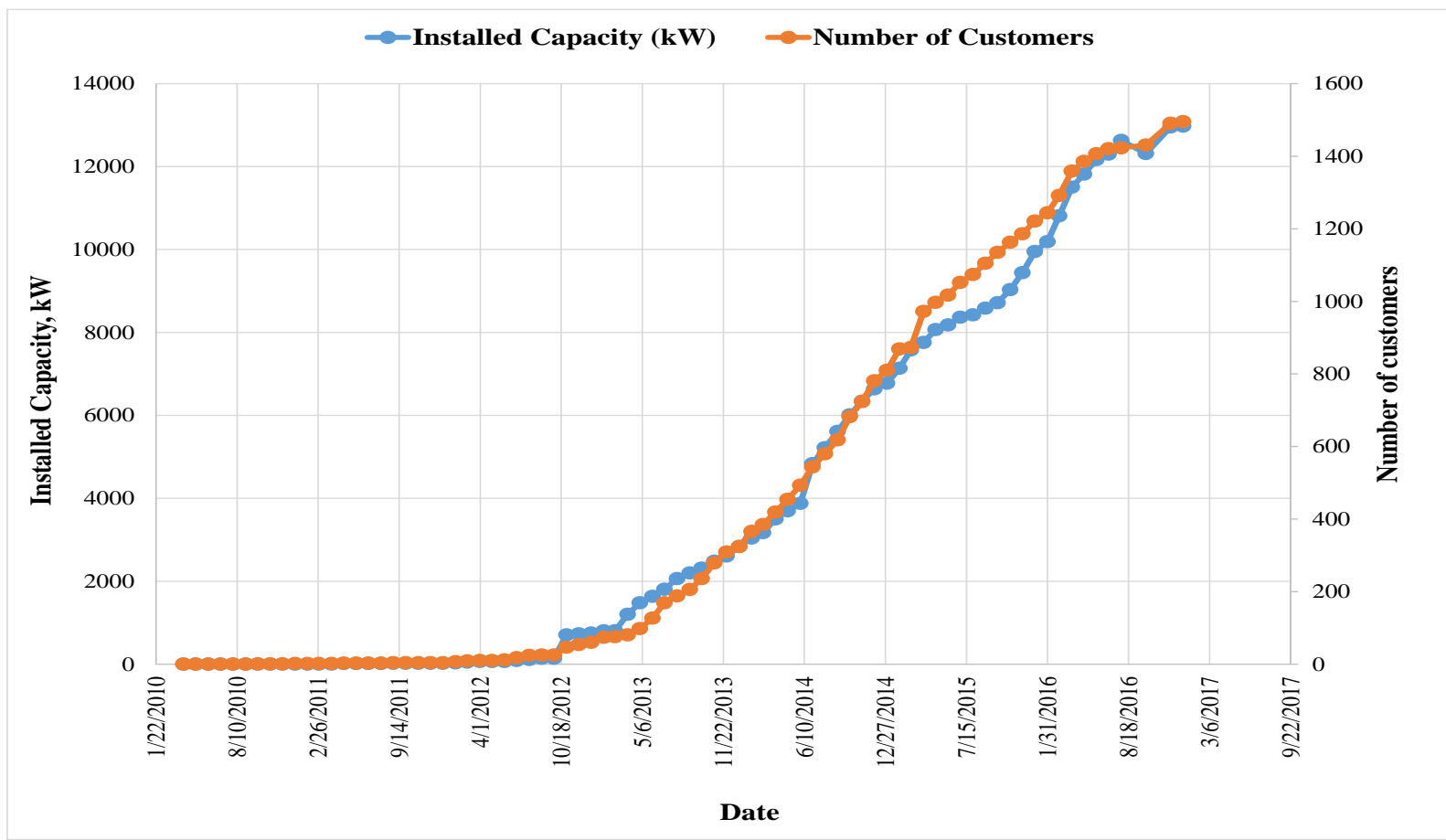

Figure 2: Renewable Energy Rider Programme Growth 2010-2016. Source: [50]. 
SWH systems do not produce electricity but have been integrated into Barbados' built environment since the 1960s for showering, cooking and cleaning purposes [22,51]. SWH research and the commercial industry first started in the 1960s and 1970s respectively [52,53].

The industry was supported by Government through the Fiscal Incentive Act of 1974 which granted tax exemptions of $20 \%$ for imported SWH raw materials, lowering installation costs by $5-10 \%$. A $60 \%$ consumption tax on electric water heaters was applied to render them unattractive [22,54]. The first large-scale Government SWH project was commissioned for a housing development in 1975, after which 1200 SWH units were further installed on four additional housing developments [28,53].

By 2002, there were over 35,000 installed SWHs; 70\% residential and 30\% commercial installations [28]. SWHs in residential homes are used for showering and cooking/cleaning purposes and commercial SWH systems are used in hotels, agriculture, food and bottling recycling [22].

According to Rogers [22], unfortunately, voluntary reporting of installation statistics of the SWH industry were suspended after 2002, due to intense market competitiveness. However, the results of the 2010 Population and Housing Census conducted by the Barbados Statistical Service [55] stated that of the 78,936 occupied houses, 26,456 have SWHs, an estimated residential penetration of $33.5 \%$. Other water heaters are used in 11,597 houses; a residential penetration of $14.7 \%$.

At the end of 2013, Barbados was ranked fourth in the world for SWH collector capacity with 319 kilowatts thermal $\left(\mathrm{kW}_{\text {th }}\right)$ per 1,000 inhabitants [22, 56] (Figure 3).

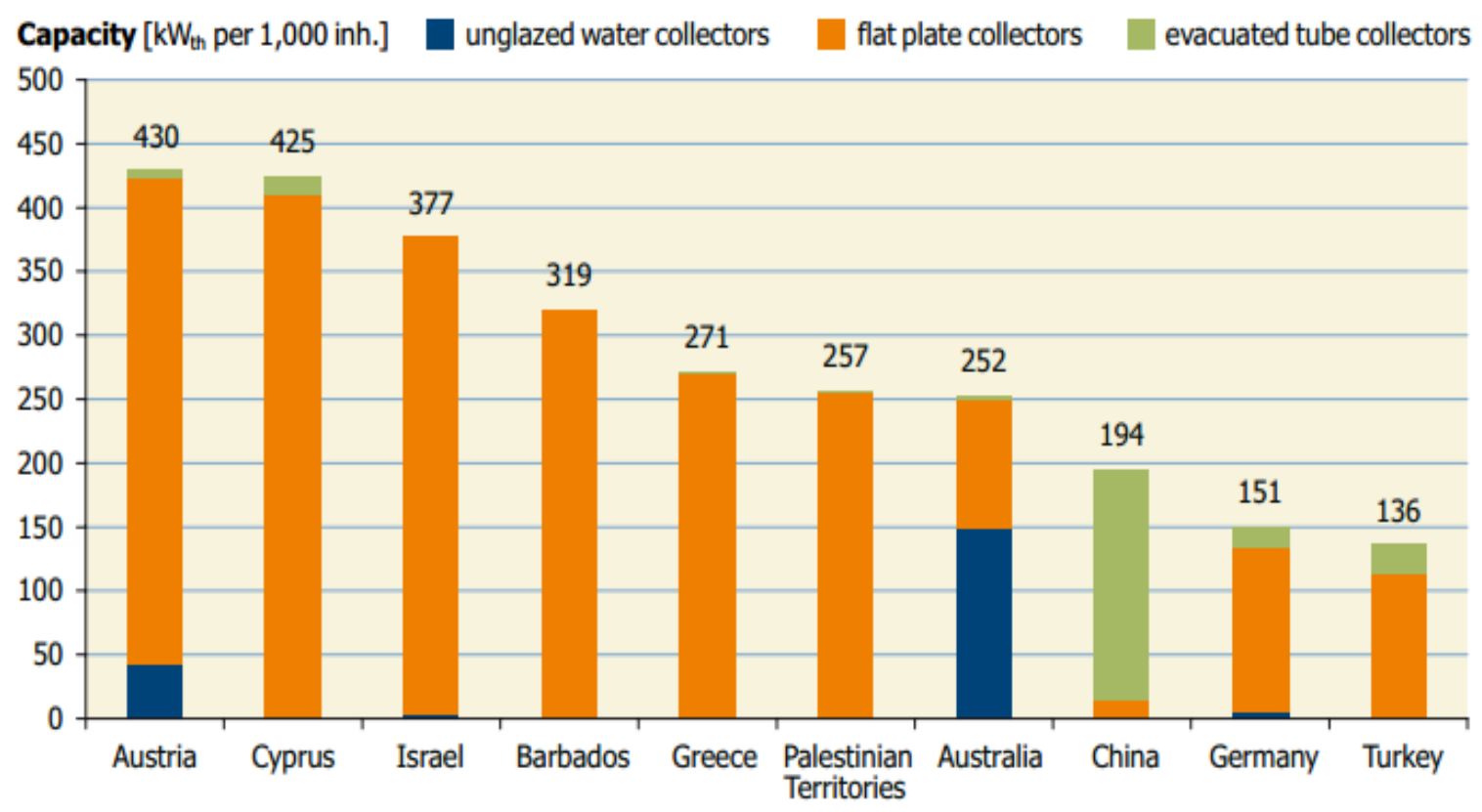

Figure 3: Top 10 countries of cumulated water collector installations (relative figures in $\mathrm{kW}_{\text {th }}$ per 1,000 inhabitants). Source: [56].

To date, Barbados has no installed capacity of concentrated solar thermal technologies, but compound parabolic concentrating solar collectors have been utilised for experimental 
purposes [46]. It is not for lack of trying that there are no installed concentrated solar thermal technologies in Barbados [57].

\section{Research methods}

The research process included data collection (Figure 4) and analysis to identify possible mitigation solutions to the uptake of solar energy in Barbados. Data collection comprised of semi-structured interviews and online questionnaire surveys. Semi-structured interviews were selected due to their effectiveness when acquiring information that enables the interviewees to express their thoughts and opinions [58]. According to Alshenqeeti, [59], talking and interacting with people is one of the most effective ways of acquiring information and interviewers can press for clear answers and delve into emerging topics.

In addition, the survey from questionnaires provided information that was used to analyse the significance of the barriers statistically. The mode of distribution for the questionnaire surveys was selected to be by web-link and e-mail, aligning with technological advancements. This is effectively due to speed, low cost, immediate review and analysis [60]. Using a flow chart, the research process is schematically illustrated in Figure 4.

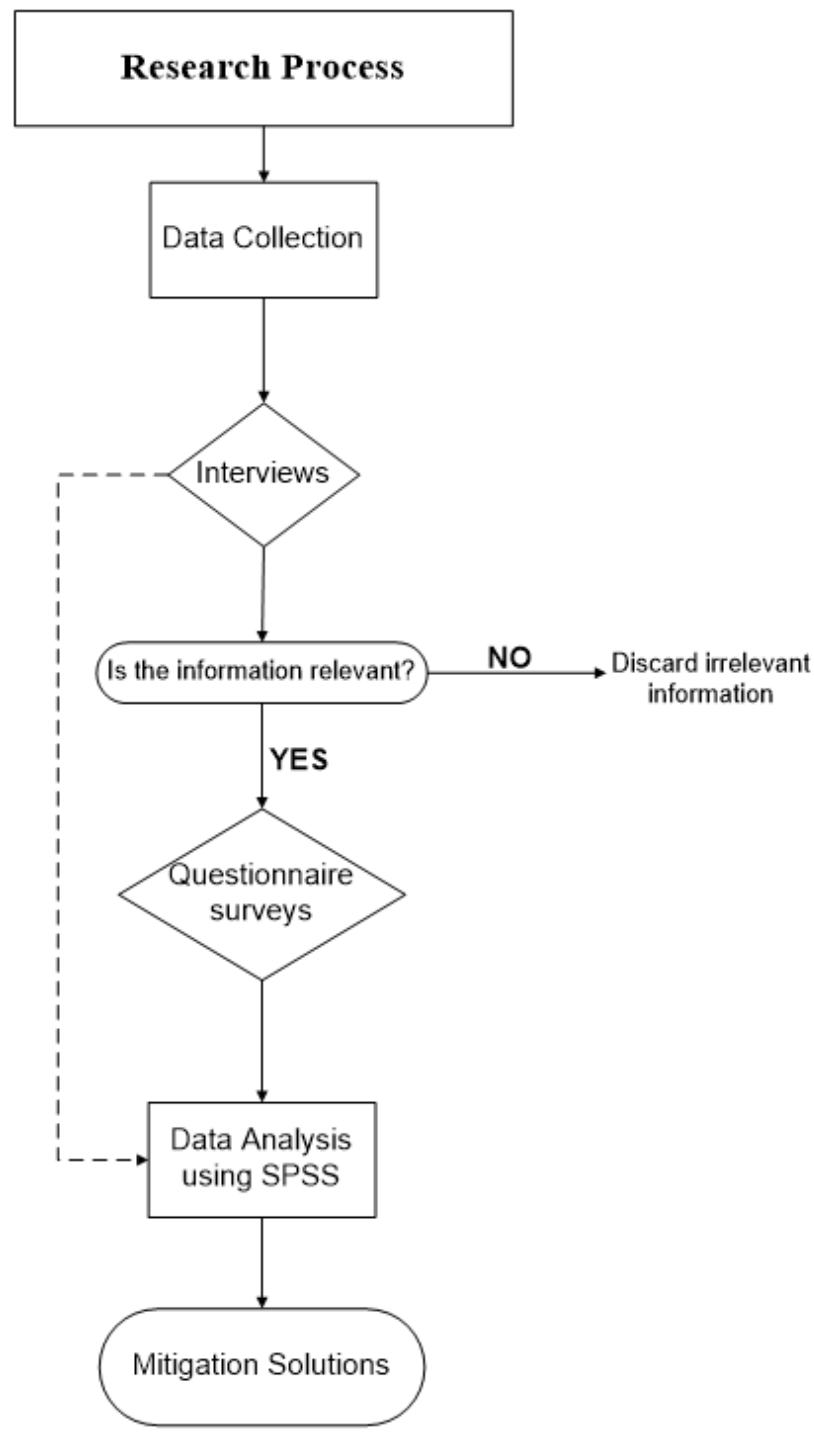

Figure 4: illustrates the research process using a flowchart. 


\subsection{Data Collection}

\subsubsection{Phase 1: Interviews}

During the research, collecting data was the major challenge due to the lack of understanding of what these researches are used for. However, 11 semi-structured interviews were conducted which included technical experts, researchers, utility representatives, a utility regulator, government energy representatives and non-governmental organisations (NGO) representatives who had knowledge and experience in the solar energy industry in Barbados. The interviews were conducted based on the availability of persons in the aforementioned categories. Table 4 presents a summary of the numbers obtained from each category cited above.

Table 4: A summary of the breakdown of personnel interviewed

\begin{tabular}{lc}
\hline Classification of the respondents & Number of Persons Interviewed \\
\hline Renewable Energy Technical Experts & 4 \\
Researcher & 1 \\
Utility Representative & 1 \\
Utility Regulator & 1 \\
Energy Representative (government) & 2 \\
Non-governmental organizations (NGO) Representative & 2 \\
\hline Total & $\mathbf{1 1}$ \\
\hline
\end{tabular}

The interviews, which lasted approximately one hour, included questions about participants' perspectives on the current state of solar energy in Barbados from a historical, social, technical, economic and political (STEP) viewpoint, as well as identifying the barriers for uptake under each category. The participants were also asked about possible mitigation measures that could be adopted for greater uptake -an objective of this research.

From the responses, 17 overarching barriers, grouped into four broad categories: social, technical economic and political (Figure 5) were identified as barriers to the uptake of solar energy. For simplicity and ease of identification, the barriers were coded using the relation in Equation 1:

$$
\text { Code }=B X \#
$$

Where,

$B=$ Barrier,

$X=\mathrm{S}, \mathrm{T}, \mathrm{E}$ or $\mathrm{P}$ (Social, Technical, Economic or Political)

$\#=$ the number of barriers within the category. 


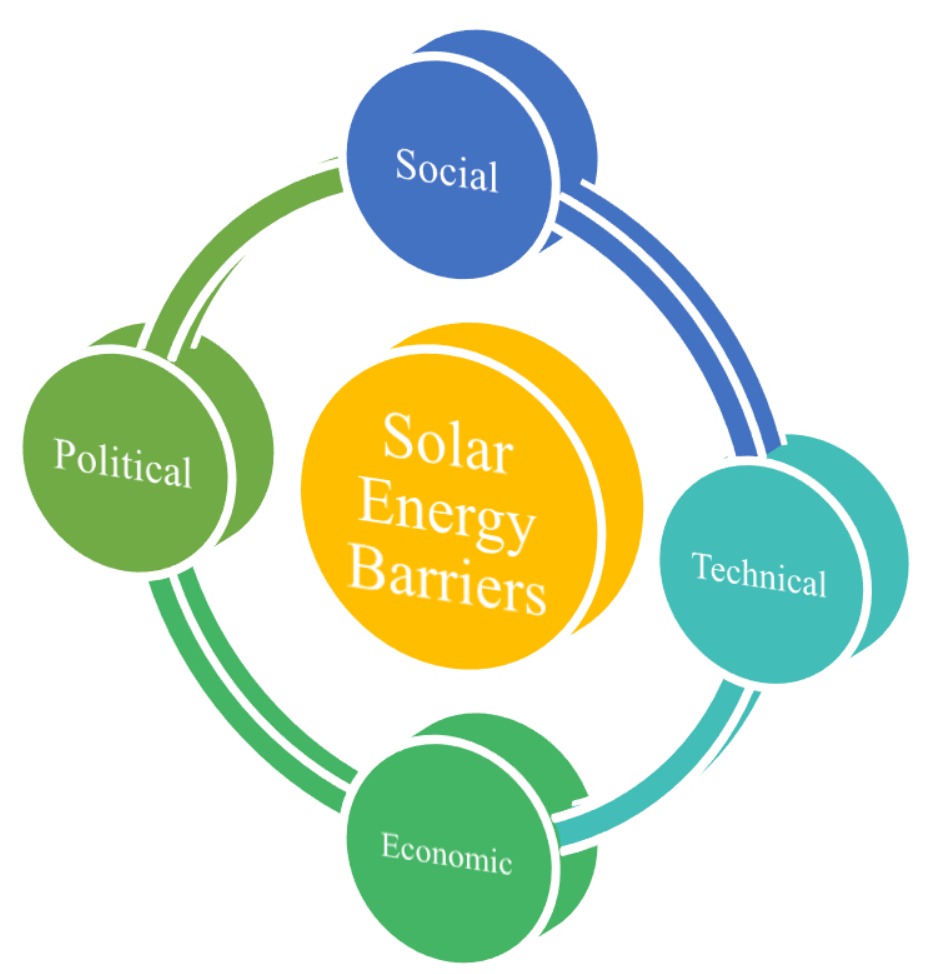

Figure 5: Categorized barriers to the uptake of solar energy technology.

The barriers identified were categorised under four broad groupings (Figure 5). The outcomes from the interviews were used to inform and formulate the design of the questionnaire surveys, which were administered online.

The 17 overarching barriers identified from this research process (Table 5), aligns with barriers identified regionally and globally. A summary of the regional and global barriers with key references are presented in Table 6, along with mitigation solutions identified from the literature. 
Table 5: Categorised barriers and sub-barriers identified from interviews.

\begin{tabular}{|c|c|c|c|}
\hline Categories & Barriers & Code & Sub-barriers \\
\hline \multirow{8}{*}{ Social } & Disinterest to change \& Complacency & BS1 & Business-as-usual-approach \\
\hline & & & Uncommonness to taking risks \\
\hline & Education \& Awareness & BS2 & Education \\
\hline & & & Awareness \\
\hline & & & Knowledge \&information \\
\hline & Social stigma & BS3 & Social economic status \\
\hline & & & Seen as a technology for the 'rich' \\
\hline & & & Not aesthetically pleasing \\
\hline \multirow{15}{*}{ Technical } & Focus, implementation \& & BT1 & Absence of export capacity \\
\hline & collaboration & & Focus shifted from SHW to PV \\
\hline & Planning process & BT2 & Tedious planning process \\
\hline & & & Land scarcity \\
\hline & Research and Development & BT3 & Building codes \& standards \\
\hline & & & Data deficiency for SHW \\
\hline & Structural iccues & BT4 & Structural integrity of roofs \\
\hline & structural issues & D14 & Outdated household electrical systems \\
\hline & & & Civil works (cabling) \\
\hline & & & Orientation \& limited roof space \\
\hline & System issues & BT5 & Poor installation \\
\hline & & & Poor or no maintenance \\
\hline & & & Ventilation \\
\hline & & & Inverters not sourced from manufacturers \\
\hline & Training \& Staffing & BT6 & Introduction of expatriates \\
\hline \multirow{8}{*}{ Economic } & Investment challenges and concerns & BE1 & Uncertainty from investments \\
\hline & & & Long payback periods \\
\hline & & & Temporary Feed-in-Tariff \\
\hline & Knowledge and systems cost & BE2 & Large upfront capital costs \\
\hline & & & Insufficient pricing information \& knowledge \\
\hline & & & Licensing fees \\
\hline & Research and development & BE3 & Macroeconomic by academic institutions \\
\hline & State of the economy & BE4 & Vulnerability of the market \\
\hline \multirow{10}{*}{ Political } & Dependence on fossil fuel for revenue & BP1 & Renewable energy sustainability/reliability \\
\hline & & & Profitability issues (and ownership) \\
\hline & Education \& Awareness & BP2 & Poor communication/stakeholder consultation \\
\hline & & & Public engagement \\
\hline & & & Non-existence of grassroots action \\
\hline & & & Staffing shortage \\
\hline & & & Leadership \& unification \\
\hline & Lack of policy/regulatory framework & BP3 & $\begin{array}{l}\text { Government restrictions } \\
\text { - Capped capacity for market/industry } \\
\text { participation }\end{array}$ \\
\hline & & & No continuity of policy if Government changes \\
\hline & Use of generic blanket approach & BP4 & - \\
\hline
\end{tabular}


Table 6: Regional and global categorised barriers and mitigation measures identified from the literature.

\begin{tabular}{|c|c|c|c|}
\hline Category & Barrier & Key reference & Mitigation measures \\
\hline \multirow{3}{*}{ Social } & $\begin{array}{l}\text { Lack of information dissemination and consumer } \\
\text { knowledge and awareness }\end{array}$ & {$[5,19,61,62,63,64,65]$} & $\begin{array}{l}\text { Education campaigns to communicate information } \\
\text { about PV and environmental effects }[62,63] \text {. }\end{array}$ \\
\hline & $\begin{array}{l}\text { Lack of trust in the information/uncertainty about } \\
\text { technology }\end{array}$ & {$[27,62,66]$} & $\begin{array}{l}\text { Certification of installers and systems and } \\
\text { performance guarantee-results schemes [66]. }\end{array}$ \\
\hline & Perception of costs and aesthetics & {$[19,62,63,65,67,68]$} & \\
\hline \multirow{5}{*}{ Technical } & Inadequate installation space and service infrastructure & {$[62,68,69]$} & $\begin{array}{l}\text { New buildings must be designed to maximise } \\
\text { installation space for solar systems [62]. }\end{array}$ \\
\hline & Lack of technical capacity and demand for electricity & {$[62,68]$} & \\
\hline & Structural issues with installing in existing buildings & [68] & \\
\hline & $\begin{array}{l}\text { Lack of necessary scientific and technical knowledge } \\
\text { and skills in the workforce }\end{array}$ & {$[10,19,26,27,61,62,63,64,65,66,67,68,69]$} & $\begin{array}{l}\text { Training programmes to provide maintenance and } \\
\text { repair services [63]; Involvement of academic } \\
\text { institutions for research and technical training which } \\
\text { involves sales and marketing [66]. }\end{array}$ \\
\hline & Lack of data \& research and development & {$[19,63,66]$} & $\begin{array}{l}\text { Creation of national database [19]; Involvement of } \\
\text { academic institutions for research [63]. }\end{array}$ \\
\hline \multirow{5}{*}{ Economic } & Long payback period and investment risks & {$[10,63,68,70]$} & \\
\hline & $\begin{array}{l}\text { Limited access to capital and lack of purchasing } \\
\text { opportunities }\end{array}$ & {$[10,26,32,61,64,65,68]$} & \\
\hline & Inadequate knowledge of costing systems & {$[26,27,62,63,64]$} & Appropriate financial schemes [62]. \\
\hline & $\begin{array}{l}\text { High initial construction/installation and maintenance } \\
\text { costs }\end{array}$ & {$[5,62,63,65,66,68]$} & Reduced tariffs for importation [66]. \\
\hline & State of the economy/ turbulent economic growth & [62] & \\
\hline
\end{tabular}


Lack of Government policy and financial support and incentives

Political

Prioritization and dependence of modern of traditional energy sources

$[32,69]$

Lack of coordination between ministries, agencies and institutions
$[27,65]$ 


\subsubsection{Phase 2: Questionnaire surveys}

The questionnaire survey was divided into two sections; $\boldsymbol{A}$ and $\boldsymbol{B}$. Section A comprised of five questions concerning the participants' background such as gender, age, employment status, job title (if employed) and educational background. The design was adopted [68] for purpose in the context of the study. Not all aspects of the questionnaire were analysed for this paper.

Section B consisted of four questions assessing the significance of the overarching barriers identified from the interviews, using the Likert scale. Each question aligned with the categories of the barriers and the participants were asked to rank each category-specific barrier as not significant, slightly significant, moderately significant, significant or very significant. The significance of the responses is rated with 1 denoting not significant to 5 very significant.

The questionnaires surveys were distributed online using a web-link for email and instant messaging platforms. The surveys were administered randomly to 61 participants of which 55 questionnaires were received ( $\sim 90 \%$ response). Table 7 illustrates the breakdown of the background of the respondents of the 55 assessed questionnaires. However, not all 17 overarching barriers were ranked and would be observed in the weighted averages over the sample size (See Table 8).

Table 7: Classification of the respondents of the questionnaire survey

\begin{tabular}{lc}
\hline Classification of the respondents & Questionnaires Received \\
\hline Renewable Energy Sector & 11 \\
Engineering & 12 \\
Manufacturing & 5 \\
Finance and Sales & 9 \\
Other* & 18 \\
\hline Total & $\mathbf{5 5}$ \\
\hline *ther represents Management, Fine Arts, Medicine and Law \& Security employment categories.
\end{tabular}

\subsection{Data Analysis}

\subsubsection{Interview analysis}

The data analysed showed that some of the barriers had a high frequency of repetition during the interviewing process. For effective comparison and weighting, the frequency was analysed using SPSS, a Statistical software. These frequencies of repeating barriers are illustrated in Figure. The top five frequently occurring barriers as identified from the analyses were education and awareness (BS2), investment challenges and concerns (BE1), lack of policy/regulatory framework (BP3), knowledge and systems cost (BE2) and structural issues (BT4). Notably, the top five barriers included all categories, with two economic barriers ranking $2^{\text {nd }}$ and $4^{\text {th }}$. These barriers were noted in this instance (approach and analyses) as the most significant. 


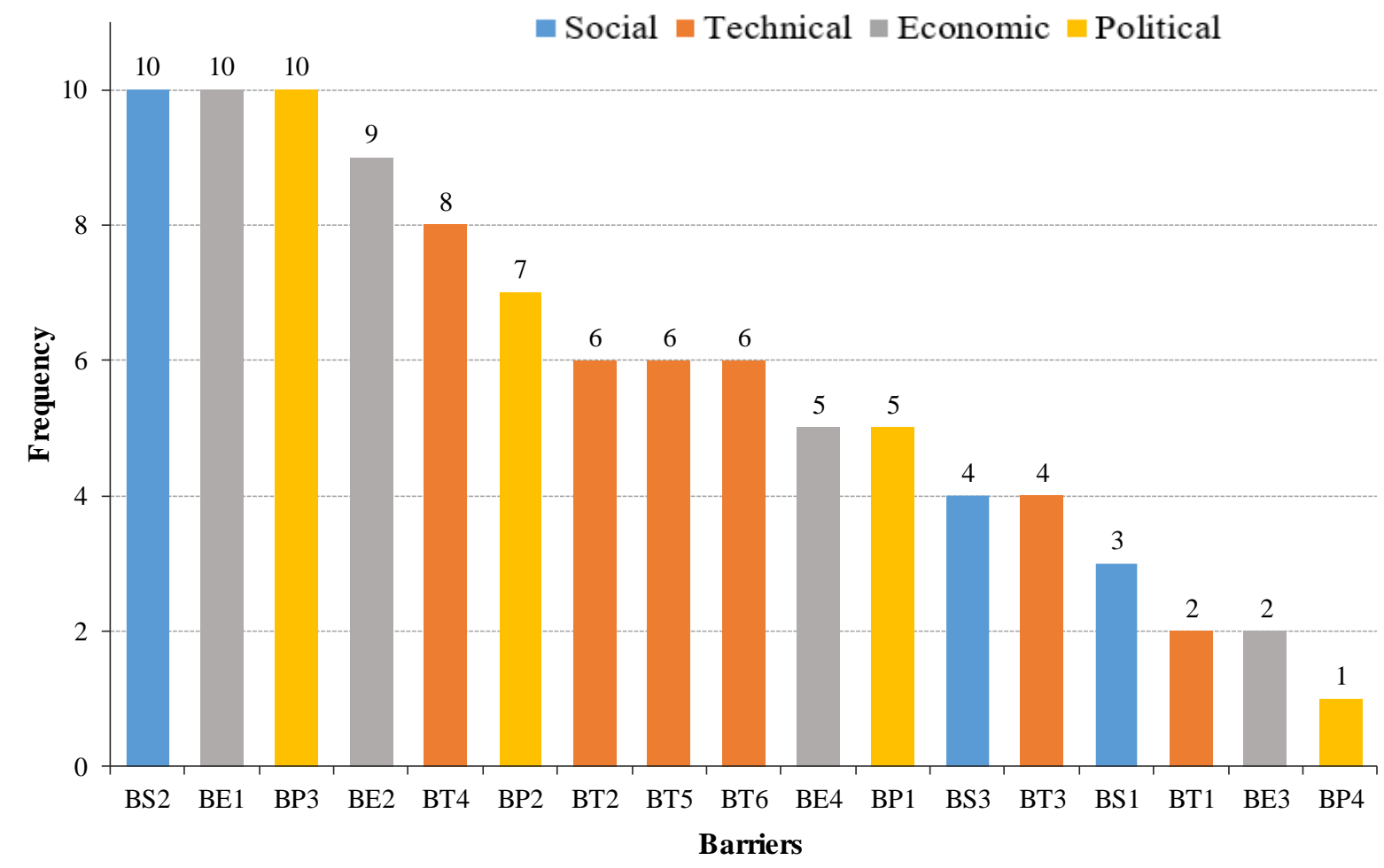

Figure 6: Frequency of barriers identified in interviews in descending order.

\subsubsection{Questionnaire survey analysis}

As discussed in section 4.1.2, incorporating the barriers identified during the interviews to inform the questionnaire survey developed a comprehensive overview. All the response from the survey were ranked according to the significance of each barrier. This was translated into a weighted average, and generated using Equation 2 as developed by Zhang et al., [68]:

$$
\text { Weighted Average }=\sum_{i=1}^{n} \frac{P_{i} R_{i}}{N}
$$

Where $P_{\mathrm{i}}$ is the rating point, $R_{i}$ is the corresponding response and $N$ is the total number of completed questionnaire surveys.

The total response of significance for the categorised barriers, as well as their corresponding analysed weighted averages, are summarised in Table. From Table 7, it is observed that the higher the weighted average score, the more significant the barrier is considered to be. Barriers with weighted averages $\geq 4.00$ were considered to be the most significant from this research. These barriers were: state of economy (BE4), investment challenges and concerns (BE1), knowledge and system costs (BE2), lack of policy/regulatory framework (BP3) and dependence on fossil fuels for revenue (BP1). It must also be noted that not all categories were completed, resulting in the varying totals observed in Table 8.

BE4's weighted average of 4.54 might have been attributed to the fact that during the period of study, the 2017 Financial Statement and Budgetary Proposals (Budget) were presented to the Barbadian public [15]. The Budget which included measures, such as increased taxes, to decrease the fiscal deficit and stabilise the economy, were deemed by the public to be severe. 
It is therefore obvious that the concerns relating to the state of the economy might be reflected in the responses.

Table 8: Weighted averages of the barriers identified from the questionnaire surveys.

\begin{tabular}{|c|c|c|c|c|c|c|c|c|}
\hline Category & Code & $\begin{array}{c}\text { Not } \\
\text { Significant } \\
(\mathbf{P i}=\mathbf{1})\end{array}$ & $\begin{array}{c}\text { Slightly } \\
\text { Significant } \\
(\mathbf{P i}=\mathbf{2})\end{array}$ & $\begin{array}{c}\text { Moderately } \\
\text { Significant } \\
(\mathbf{P i}=\mathbf{3})\end{array}$ & $\begin{array}{c}\text { Significant } \\
(\mathbf{P i}=4)\end{array}$ & $\begin{array}{c}\text { Very } \\
\text { Significant } \\
(\mathbf{P i}=5)\end{array}$ & Total & $\begin{array}{c}\text { Weighted } \\
\text { Average }\end{array}$ \\
\hline \multirow{3}{*}{ Social } & BS1 & 6 & 5 & 13 & 17 & 10 & 51 & 3.39 \\
\hline & $\mathrm{BS} 2$ & 1 & 4 & 10 & 18 & 17 & 50 & 3.92 \\
\hline & BS3 & 13 & 10 & 10 & 7 & 9 & 49 & 2.78 \\
\hline \multirow{6}{*}{ Technical } & BT1 & 0 & 7 & 12 & 19 & 12 & 50 & 3.72 \\
\hline & BT2 & 0 & 4 & 10 & 21 & 16 & 51 & 3.92 \\
\hline & BT3 & 2 & 2 & 9 & 24 & 14 & 51 & 3.9 \\
\hline & BT4 & 4 & 4 & 10 & 19 & 14 & 51 & 3.69 \\
\hline & BT5 & 4 & 4 & 15 & 16 & 12 & 51 & 3.55 \\
\hline & BT6 & 0 & 7 & 11 & 16 & 17 & 51 & 3.84 \\
\hline \multirow{4}{*}{ Economic } & BE1 & 1 & 0 & 2 & 25 & 22 & 50 & 4.34 \\
\hline & BE2 & 1 & 3 & 3 & 24 & 19 & 50 & 4.14 \\
\hline & BE3 & 1 & 5 & 10 & 20 & 14 & 50 & 3.82 \\
\hline & BE4 & 0 & 0 & 4 & 15 & 31 & 50 & 4.54 \\
\hline \multirow{4}{*}{ Political } & BP1 & 1 & 3 & 9 & 19 & 19 & 51 & 4.02 \\
\hline & BP2 & 1 & 3 & 11 & 19 & 17 & 51 & 3.94 \\
\hline & BP3 & 2 & 4 & 4 & 20 & 21 & 51 & 4.06 \\
\hline & BP4 & 4 & 3 & 18 & 15 & 8 & 48 & 3.42 \\
\hline
\end{tabular}

Solar energy technologies are expensive and within Barbados' economy, BE1 might have been regarded as a significant barrier because of lack of disposable income and financing knowledge. Apart from the lack of disposable income available, the participants indicated that there is also a lack of knowledge and systems cost (BE2) for solar energy technologies.

In another development, the high significance responses of BP3 might have been influenced by Barbados' energy policy, which is still in its draft phase but has a significant impact on influencing the financial sector with respect to the cost of renewable energy systems.

BP1 ranking within the top 5 indicates that participants are aware of the country's dependence on conventional energy (fossil fuels) and how it is recognised as a barrier to solar energy uptake.

A graphical representation of the barriers and respondents outputs (Table 8) is illustrated in 


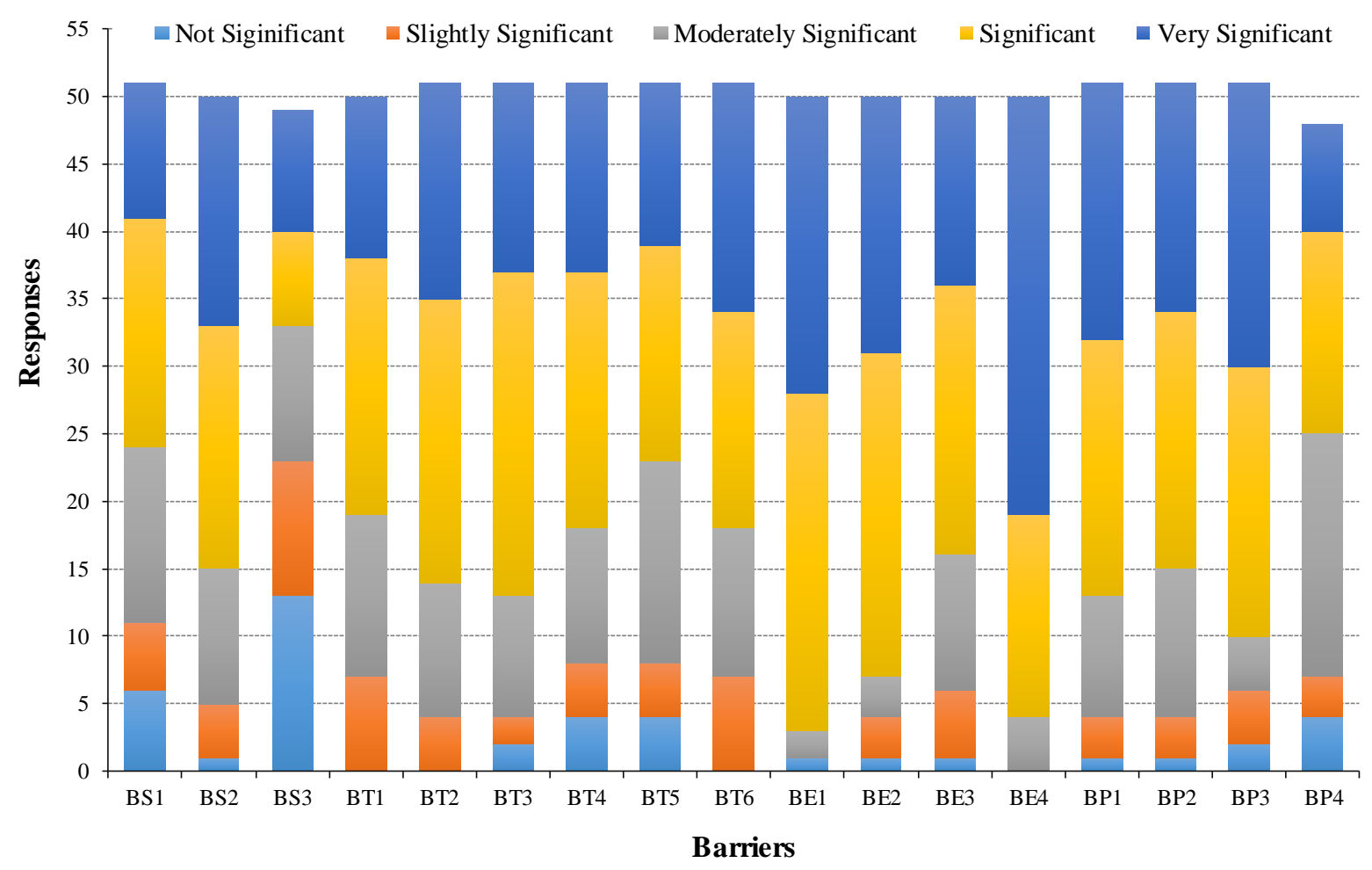

Figure 7: Responses of the questionnaire survey, expressed using the Likert scale.

From Figure 7, the top five barriers (BE4, BE1, BE2, BP3 and BP1) with weighted averages of $\geq 4.00$, had most respondents ranking significant and very significant.

Overall, sixteen of the seventeen barriers had $50 \%$ or more of the respondents ranking significant and very significant. BS3 was viewed as not significant to moderately significant by the respondents indicating a level of approval of solar energy technologies integrated into the built environment.

\subsection{Comparison of results between Interviews and Questionnaire Surveys}

To compare the frequencies from the interviews and the weighted averages from the questionnaire surveys, the percentage response was used for like terms. For the questionnaire surveys, the number of responses ranked as significant and very significant were taken as percentages of the total responses for each respective barrier. For the interviews, the frequency of response for a barrier per interview was considered as a percentage of the total number of interviews conducted. The summary of these results is illustrated in Figure 8 to show the comparison of the percentage responses for the interviews and questionnaire surveys. 


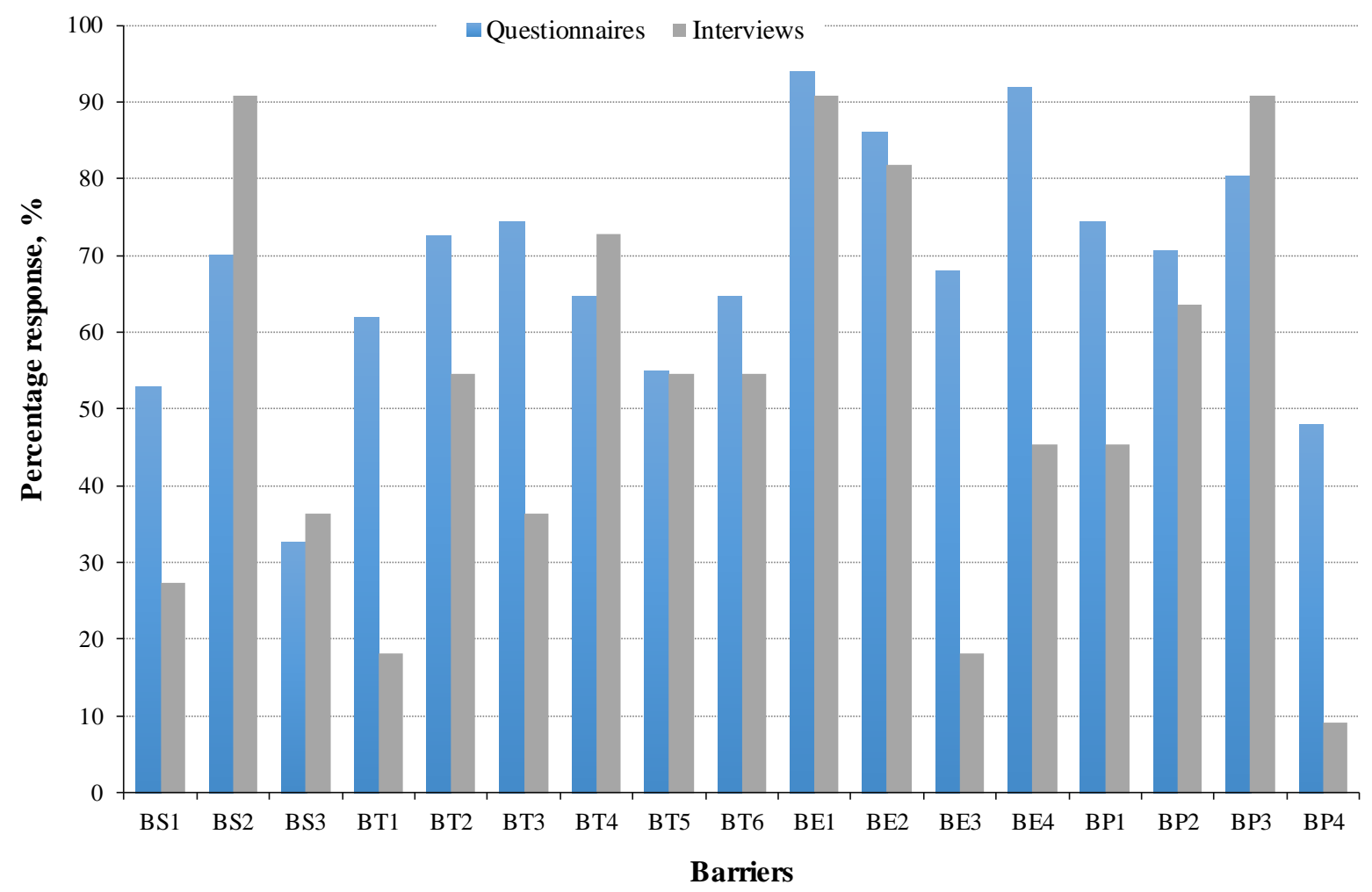

Figure 8: Percentage responses of questionnaire surveys versus interviews.

To provide relevance to the study and hence identifying mitigation measures, the top five barriers with the highest percentage responses from the questionnaire and interview surveys were considered. In terms of the questionnaires, there were two barriers with the same percentage hence the top six were considered. These were BE1, BE4, BE2, BP3, BP1 and BT3. $\mathrm{BP} 1$ and BT3 both had a percentage response of $75 \%$. However, the percentage responses from the interview were not completely aligned with that of the questionnaire survey results. Form the interviews; Figure shows that the top five ranking barriers were BS2, BE1, BP3, BE2 and BT4. Barriers BE1, BE2 and BP3 are noted to reoccur in the top five for both the interviews and questionnaire surveys (Figure 8). It must be noted that any set of barriers could have been selected for analyses, however in this research, only the top 5 for each method was considered.

Following on from the selection of the 'top 5' barriers from the interviews and questionnaires, altogether eight barriers were noted to be of significance due to the overlap of barriers and the hierarchical status discussed above. These eight barriers are: BE1, BS2, BP3, BE4, BE2, BT3 BP1 and BT4.

\section{Results and discussion}

These eight collective barriers are further discussed in the sub-sections following, in descending order of percentage response. 


\subsection{Investment challenges and concerns (BE1)}

Investment challenges and concerns were regarded as significant barriers to the uptake of solar energy globally and regionally due to longer payback periods, higher investment cost compared to traditional energy sources. Eleftheriadis \& Anagnostopoulou, [67] note that there are also financial risks associated with lack of/inadequate institutional and regulatory frameworks. At present, there is a temporary Feed-in-Tariff (FiT) for solar photovoltaics, \$0.416/ kWh. However, there are investment concerns because there is no set period (e.g. 3 years or 10 years) for which the FiT is applicable. The temporary FiT has contributed to market contraction, resulting in solar energy company closures. The FiT is considered a liability for investors who are reluctant to invest, especially within the current economic climate. Challenges and concerns surrounding investments would continue to be a barrier under the current temporary FiT and the state of the economy; however, the development of a tariff programme, set for the lifetime of the system could mitigate this barrier. The programme would guarantee a return on investment and shorten the payback period. In essence, measures were suggested as noted in the interview response quoted as follows:

"If you have a feed-in-tariff for about 20 years, some commercial banks can see the benefits and security is in a much more friendly light- a much more positive light. What we have now is a fixed rate but it's still temporary and that still adds a measure of insecurity" (Representative from NGO, 2017).

The response is echoed by the fact that countries such as the United Kingdom uses a FiT scheme with tariff rates set for a guaranteed time of approximately 20 years, for renewable technologies. Tariff rates range between high, medium or low depending on the technology [71].

\subsection{Education and awareness (BS2)}

Education and awareness were regarded to be the other major inhibitors to the dissemination of solar energy technology. In a study by Karakaya and Sriwannawit, [62], it was concluded that less application of photovoltaics systems was attributed to lack of technological awareness, concerns of system complexity, technological maturity, durability, efficiency and safety. Due to the high percentage of installations, Barbadians were regarded to have knowledge about SWH from technical experts. However, two photovoltaics (PV) installers indicated that there are continual uncertainties existing between PV and SWH. Indeed, the representatives pointed out that:

"At the moment the public is well aware of solar water heating and I have no doubts about that. They do get confused between the two, solar water heating and photovoltaics. If you tell someone that you do solar energy, the average person would pretty much default to solar water heating and they may not be aware of the difference between the two and they may ask, 'Is the solar energy system also heating water?'. So there is still public knowledge that is lacking. (Representative 1, 2017)

Predominately, there is a lack of understanding of the technology. There are a lot of people who blur solar thermal with photovoltaics. They have no idea of the difference" (Representative 2, 2017).

Here, the representatives highlight the need to provide awareness and articulate technology (PV and SWH) to the public since this is significantly lacking. The lack of know-how in this 
field is reviewed by the Barbados Renewable Energy Association to stimulate education and awareness within the public through 'Consumer Guide: Solar PV', a published document. The guide distinguishes SWH systems from PV, types of PV, components, installation considerations, finance information and energy efficiency [72]. Their work is extended to the communication and sensitisation planning for various demographics of Barbados, as well as a training and certification programme in energy management for sectoral professionals [73].

It is envisaged that $\mathrm{BS} 2$ can be alleviated by educational campaigns and curriculum to communicate information about solar energy and environmental effects. Karakaya and Sriwannawit, [62] and Mondal, et al., [63], echo this. Over the last decade, social media has emerged as one of the dominant forms of information dissemination through blogs, social networking websites and video and photo sharing sites. Social media can be used to promote mindfulness about the technologies since it can influence behaviours through awareness, information acquisition, opinions and attitudes [74] and has the ability to reach the wider population of Barbados.

\subsection{Lack of policy/regulatory framework (BP3)}

Whilst education was noted to be essential, the lack of policy/regulatory framework was identified as a significant barrier from both interviews and questionnaires. The Interim Draft of the National Energy Policy for Barbados 2017-2036 is currently under review and awaiting approval [10]. This seems to support the view that:

"This [the policy] should have been done a long time ago. At least we could have started work on this in 2012, but our focus was not where it should be. Instead of focusing on the energy sector, we were more concerned about the short-term financial benefits that we could extract. As a result, we found ourselves in a particular situation where we are behind the curve, the long-term has now caught up with us, and we have not advanced" (Representative from the Government, 2017).

Indeed, the fact that there is currently no national energy policy in this regard is a significant barrier. There is no doubt that, the successful promotion of renewable energy involves developing policies and frameworks that are integral in managing high initial investment costs and competitiveness [10]. Niles and Lloyd [69] concluded that policies are considered as a prerequisite to accessing funds from international donor institutions which could enhance the acquisition of these technologies.

Other issues stemming from the lack of a national energy policy, is the lack of communication and consultation with stakeholders and the general public. One interviewee states that:

\footnotetext{
"We have a policy that is in the final stages, and they have not sought that broad base consultation with the Barbadian public" (Representative from the utilities regulatory body, 2017).
}

Clearly, the rise in prominence of any technology is engaging with the feedback from the endusers since, in this instance, the public and stakeholders are integral participants in the administrative processes and governance structures necessary for the implementation of policies, legislation and regulatory frameworks [75]. Nevertheless, this has been overlooked resulting in the lack of communication and involvement from major stakeholders is considered to be one of the reasons for the delay of a viable policy. From this research it is evident that the 
formulation of a formidable policy would go a long way to affirm the uptake of solar energy technologies as echoed:

"The policy is really the start. You need the finalisation of the national policy, because the national policy is really going to set the paces on how the sector goes forward" (Representative of NGO, 2017).

It is argued that through the systematic identification, analysis, planning and implementation of actions that engage stakeholders (stakeholder management) [76], participation and management would identify concerns, allow the sharing of knowledge to improve cohesiveness and lead to energy policy adoption [77,78].However, this is still lacking as evident in the response from this study.

\subsection{State of the economy (BE4)}

There is a growing dilemma, which has a direct impact on the economy of Barbados. The country finds itself in a complex situation where the revenue from fossil fuel pays Government wages and salaries, but at the same time, the government is pushing for the uptake of renewable energy application to reduce fossil fuel usage. The main concern is that there is no other revenue stream to substitute for the potential loss of revenue from fossil fuels if renewable energy technologies are adopted to meet targets. This situation is further explained in the following quote:

"On one hand, you have sort of a conundrum where Government is actually earning money to pay salaries and to keep people employed from fossil fuels. When you go to the pump and you get your tank filled up, or half-filled, the excise tax from that goes into Government revenue to pay its bills. On the other hand, Government is pushing for $65 \%$ renewables in the economy by 2030. Government recognises that if oil prices continue to rise, as projected that means the Government would have to spend a lot more money to earn the foreign exchange that pays for the increase in quantities offossil fuels. So it recognises a movement towards sustainable energy strategy, to attempt to avoid exposing the economy to sharp price rises in fuel. As a result focusing on renewables hence the reduction of fossil fuel use" (Representative from a NGO, 2017).

In efforts to accumulate more revenue in addition to excise tax on fossil fuels, the National Social Responsibility Levy (NSRL) has had profound negative effects on the renewable energy sector in Barbados and is highlighted in the following response:

"Recently, we saw how vulnerable the market can be. One day everything was functional, paying no duties, paying no VAT and then we were hit with a social responsibility tax. This tax excludes agriculture, tourism and manufacturing but does not exclude renewable energy. The investment in renewable energy can easily be seen as a social responsibility to start with. Furthermore, as a growing market, the Government refused to withhold the $2 \%$ tax on renewable energy, which is currently in place" (Representative from a solar energy company, 2017).

The President of BREA stated that further increase of the NSRL to 10\%, "could very well kill the country's fledgeling renewable energy sector" as it would result in increased operating costs and prices for customers [79]. 
From the previous research such as the Sustainable Energy Framework for Barbados [21], renewable energy has been regarded as a sector for potential growth by the GoB. However the exemption of the renewable sector from the NSRL is contradictory to reaching renewable energy targets.

The state of Barbados' economy is far from recovery; nevertheless, if the GoB has high prospects for the development of the renewable energy sector, legislation such as the national energy policy could protect the sector from budgetary measures, such as the NSRL and exempting the sector from this levy would facilitate market growth.

\subsection{Knowledge and systems costs (BE2)}

In Barbados, high upfront capitals costs and licensing fees are prohibitive to greater uptake, especially for those of a lower income class. Costs are affected by policy mechanisms in place or lack thereof, and the cost of traditional energy sources may be cheaper in comparison [62]. The capital cost of SWH and electric water heaters is considered to be high echoed in the following quote:

"A solar water heating system could range anywhere between \$3500, when AquaSol was there for an 80-litre system and I think going all the way up to $\$ 5000$ and $\$ 5000$ plus for a system. Now certain income groups will not be able to afford that and they are seeking assistance from Government to investigate- to do some further investigation to see what could be done to reduce that cost, so that lower income groups can access it. An electric heater upfront cost is cheaper but I can pay a little more on the electric bill to heat the water because I cannot pay out $\$ 5000$ at once, in one go. The cost is a bit prohibitive" (Representative from the Government, 2017).

The fact that the average cost of purchasing and installing an electric water heater is \$796 BDS, while the purchasing and installation price (a one-time price) for an 80 litres WH system costs approximately $\$ 4000$ BDS renders the latter approximately 5 times more expensive. With regards to upfront cost, an electric water heater is more affordable, but it incurs an additional cost of approximately \$1551 BDS per year in electricity while the SWH systems have annual savings of \$1759 BDS [80]. Unfortunately, this information is not widely disseminated to the public, which could be one of the key reasons why the penetration of solar water heating systems is approximately $33.5 \%$.

Also, the amount of disposable income is often linked to one's income class and large upfront capital costs are more likely to be manageable for those in the middle to upper-income class. Another case for concern is the licensing fees for IPPs under the ELPA, which have affected installers and potential customers as highlighted by a representative:

"What effectively they have said, is that when you hit $150 \mathrm{~kW}$, punish you. So whatever benefit you get from installing the $150 \mathrm{~kW}$, we are going to take away a sizeable portion of that benefit in license fees- to $\$ 7000-\$ 8500$ a year" (Representative from a solar energy company, 2017).

In addition, despite the fact that the cost of solar photovoltaics has decreased globally over time, unfortunately photovoltaic modules and system components, are still subjected to the NSRL making it relatively expensive. As explained in section 5.4, costs are expected to rise 
under the extended NSRL and this barrier cannot be mitigated unless the renewable energy sector becomes exempted as in the case of agriculture, manufacturing and tourism.

\subsection{Research and development (BT3)}

According to Mondal, et al., [63] research and development should be performed on renewable energy technologies to ensure optimum national suitability. Research and development is also integral for alleviating technical barriers, reducing costs and increasing design innovation $[27,66]$.

In the context of this study, research and development has been unhurried for solar technologies and current data is necessary for the structure and delivery of programmes to boost uptake. This view is highlighted below:

"So, you need to be able to facilitate the necessary research and development, research and analysis, because that will guide the basis on how you begin to structure your programmes. Without that level of empirical data and that level of analysis, we are shooting tubs" (Representative from NGO, 2017).

This barrier could be mitigated by further involvement of academic institutions in Barbados and other CARICOM countries for research and development. The creation of a national database of data for solar energy (and other renewables) as suggested by [19] would be the foundation of the renewable energy sector. Data would then be available for the development and improvement of national building standards and codes.

\subsection{Dependence on fossil fuels for revenue (BP1)}

Barbados produces approximately 500 BOPD to 1000 BOPD equivalent of natural gas, which only accounts for $14 \%$ of the country's energy demand [10]. The remaining $86 \%$ is acquired through the importation of heavy fuel oil, jet oil and diesel for electricity generation and transportation, at a cost which fluctuates well above $\$ 400$ million Barbados dollars [11]. The dependence on fossil fuels is widely known by Barbadians, as the price of petrol and diesel increases with increasing world oil prices and more recently, increases caused by taxation. Barbados' large debt is significantly attributed to the cost associated with the importation of fossil fuels, as stated in the following quote:

“The Central Bank of Barbados' 2016 balance of statements indicated that our[Barbados] physical debt is due to the large amounts of money spent on fossil fuels" (Representative from NGO, 2017).

In addition, government wages and salaries (approximately $\$ 400$ million Barbados dollars) are managed by means of excise tax applied to the purchase of diesel, gasoline and the generation of electricity, as mention previously in BE4. Unfortunately, there is no other revenue stream in place to sufficiently cover government wages and salaries from fossil fuels and Barbados' electrical grid is predominately operated from fossil fuels. This view is highlighted below:

"The Government of Barbados collects revenue for oil. They import the oil, sell it to whoever who ends up putting that into their cars, creating cash flow from oil. If the leaders want to go $100 \%$ renewable and remove oil, then the question is, where do we get the revenue from and how do we transition smoothly so that no one is left out in the cold. Similarly, looking at the utility, if you are implementing $100 \%$ renewable energy 
overnight, then you will have stranded assets because the utility will have a 25 year plan, so it would be unfair for an investor to sign an agreement with the Government for the next 25 years to deliver a service as important as electricity while the Government makes the decision that would put them out of work 10 years earlier" (Representative from a solar energy company, 2017).

Dependence on fossil fuels can only be mitigated by increased usage of renewable energy technologies in electricity generation and the transportation sector, the two largest consumers of fossil fuels in Barbados. However, due to the revenue required by the Government to pay its bills, the country's physical debt and the poor state of the economy, the heavy dependence on fossil fuel seems to increase instead of decrease thereby inhibiting the potential deployment of renewable energy technologies as a mitigation solution.

\subsection{Structural issues (BT4)}

The final significant barrier arising from the interviews pertains to structural issues such as structural integrity of roofs, outdated electrical systems, civil works and limited installation space. Under the context of structural soundness, the following quote states:

"We still do get problems with rooftops because if you are going to install a photovoltaic system that will last for twenty years, we have to make sure that the roof will be there for twenty years as well, so that it's able to support the photovoltaic system" (Representative from a tertiary institution, 2017).

Photovoltaic installers indicated that customers report roof and electrical assessments and they are advised to change either their roofs or service them before installation can commence. This then creates, additional cost. One of the installers indicated they have waited up to a year for renovation completion before installation.

Residential buildings with old electrical installations, also present a challenge for the electrical connection of photovoltaic systems, as they require upgrades. An installer's point of view is presented:

"Many older homes that were wired in the 60s and before, [have] single phase and cannot accommodate the technology. This is rather concerning since we have lost customers who could not meet the electrical specifications. This includes some commercial customers. The cost of retrofit work that is required to qualify for a modern grid, a smarter grid and therefore the power company, deters customers. You can't expect them [the power company] to take on something that is going to bring their grid down and because effectively that is what it is going to do" (Representative from a solar energy company, 2017).

Also related to electrical systems, are the civil works needed to facilitate the retrofit.

"Some of the other technical barriers that will increase cost are how the house was wired. For instance, a lot of people have ended up with their meter at the entrance of the guard wall of the house- 100 meters in or 50 meters in. Trenching to allow for metering has increased civil works retrofitting, a feature that is occurring as a technical barrier" (Representative from a solar energy company, 2017). 
Retrofitting activities is paramount for residential and commercial buildings that do not have the adequate structural and electrical infrastructure to sustain solar energy systems. Unfortunately, major retrofitting significantly increases the cost of an already expensive installation process. This is often, if not always, regarded as a barrier for the uptake from this research.

From this research, BT4 can be mitigated through standards and building codes, which mandate that new buildings must be designed to maximise installation space for solar systems [62]. The adoption of standards was also introduced as a mitigation solution from the interviews in a statement below:

"Engineers must meet a certain standard-professional standard-in terms of how they practice. You need for you energy installers to meet at least the minimum standards or in terms that they agree to produce a certain level of work, so that you don't have issues where they are installations that would take place on incompatible houses or that the framework doesn't support a photovoltaic system. So that can someday also be incorporated through code of practice or a standard for energy installers" (Representative of NGO, 2017).

\subsection{Mitigation solutions}

The framework diagram illustrated in Figure 9 summarises the mitigation solutions for the top eight barriers identified from this research. The connectivity of how these barriers influence each other is also illustrated. From the research, eight mitigation solutions (Figure 9) were deemed to be of importance to the solar (renewable) energy sector of Barbados. These were derived from the seventeen overarching barriers identified throughout this research. Notably, the finalisation of a clear, definitive national energy policy was the most echoed from the response as the bedrock to rectifying and eliminating barriers to the deployment of solar energy. It is anticipated that completing and commissioning the energy policy would eventually drive the renewable energy market forward. Consequently, it is anticipated that other mitigation solutions within the proposed framework would also benefit from commissioning of the policy. This no doubt encases the strands of sustainable microgeneration; social, technical, economic, environmental and policy (STEEP) most of which are captured in this research (See Figure 5 and Table 5).

Despite the fact the environmental aspects of sustainable microgeneration, in this context using renewable energy technologies have not been factored into this research it is a vital component in achieving sustainability. Akinyele et al, [81] argue that renewable energy technologies such as solar can be described as environmentally friendly, as their immediate generation of electricity does not incur environmental impacts. However, when considering the cradle-tograve life-cycle assessment of solar energy technologies, there is undoubtedly carbon footprint associated to the manufacturing, installation, maintenance, and decommissioning and disposal process. As a result, ensuring environmental assessment and environmental awareness remains crucial to policy development, to account for these overshadowed impacts.

This is no doubt a significant aspect at the forefront of the policy makers hence it is in the light of this that, the environmental mitigation measures are stipulated within the Interim Draft of the National Energy Policy of Barbados (NEPB). The NEPB [9] puts a lot of emphasis on the environmental concerns in the draft policy accounting for, and seeking to fulfil the following: 
- Establish standards and protocols for the safe and effective disposal of equipment and devises in the energy sector

- Establish a decommissioning fund for the energy sector to facilitate the decommissioning and abandonment of energy operations and facilities

- Establish standards and protocols that promote and encourage the goal of zero harm to the people and the environment in the production of energy in the petroleum and renewable energy sub-sectors

- Establish information systems and infrastructure that promotes the flow of information requiring environmental standards, best practices and legislation.

The quest for solutions to the eight mentioned barriers (Figure 9) and others cited in this research (summary in Table 5) that inhibit the uptake of renewable energy technologies remains among the major research emphasis for Barbados which has been clearly defined in this study and aligned with similar concerns and mitigation requirements worldwide as emphasised in Table 6.

\section{Barriers}

Mitigation Solutions

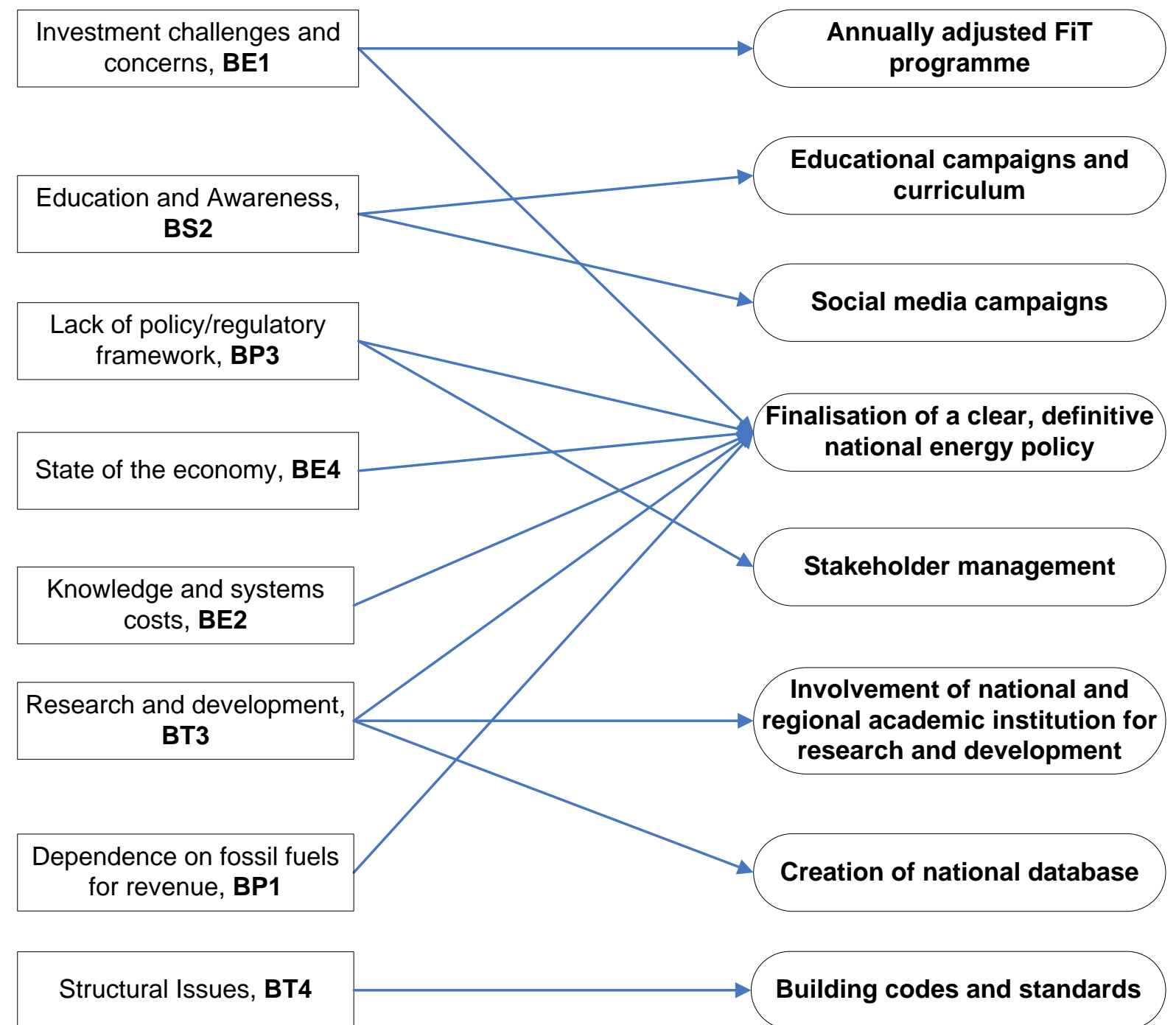

Figure 9: Framework of mitigation solutions. 


\section{Conclusions and Recommendations}

The dependence on the importation of fossil fuels for electricity generation and transportation has continued to influence the inception of alternative energy sources in Caribbean SIDS. However, efforts are underway to reduce fossil fuel usage through renewable energy technologies such as solar, wind, geothermal and biomass energy. To date, the Caribbean has a total installed capacity of 2,435 MWe of renewable energy, of which solar energy accounts for $433.5 \mathrm{MWe}$. This is still a long way from measure accepted to meet stipulated targets.

In Barbados, solar photovoltaics have been integrated into the built environment since 2010 through the RER programme and the island is ranked $4{ }^{\text {th }}$ globally for SWH capacity per 1000 inhabitants. Nevertheless, to date, there is no installed capacity of concentrated solar technologies in the country from literature.

To this end, the aim of this research was to investigate the barriers preventing the uptake of solar technologies and to identify possible mitigation measures for the barriers identified. Past barriers to the uptake of solar energy in Barbados were investigated through the review of the literature. Present barriers were investigated through the analysis of eleven interviews and fiftyfive questionnaire surveys. Seventeen principal barriers were identified from the interviews, supported by the literature. Eight barriers were found to be the most significant from both survey methods using percentage responses:

- Investment challenges and concerns, BE1

- Education and awareness, BS2

- Lack of policy/regulatory framework, BP3

- State economy, BE4

- Knowledge and systems costs, BE2

- Research and development, BT3

- Dependence on fossil fuels for revenue, BP1

- Structural issues, BT4

BE1 was attributed to the temporary FiT, which is liable for investors, as there is no guaranteed return on investment, resulting in longer payback periods. Confusion also exists between photovoltaics systems and SWH, due to lack of education and awareness, but work is underway with BREA to inform and sensitise the public.

It is obvious from research that the disposable income needed for solar energy systems are seemingly achievable for only medium to upper-income class citizens, which is rather unfortunate considering the energy needs of those who fall below this income bracket.

In addition, through research and development building codes and standards for solar technologies would be updated with relevant information and data. This would then minimise/eliminates the four structural issues identified from research (Figure 5).

As evident in the research output without a national energy policy, shaping the renewable energy sector would remain a challenge. This is echoed in the findings, suggesting that a national energy policy can potentially mitigate against barriers BE1, BP3, BE4, BE2, BT3 and BP1. This notwithstanding, other mitigation solutions; educational campaigns, stakeholder management, creation of a national database and building codes and standards were also identified as fundamental to ensuring the implementation of RE sources. Despite these, 
structural issues remain a concern with possible mitigation solutions including retrofitting, although it comes with an inherent cost.

Although significant data was collected, this research was limited by insufficient interviews with technical experts and installers specifically for SWH systems. It is recommended that a comprehensive list of all solar photovoltaic and SWH installation companies be compiled in a database to ensure access for research. This database would be an asset for future policy development and research conducted on Barbados' solar energy industry by Government, NGOs and academic institutions.

If Barbados were to reach $65 \%$ renewable energy by 2030 and succeed at reducing fossil fuel costs, the mitigation of the barriers identified in this research would result in a greater uptake of solar energy, which would then allow the country to meet its obligations to achieving a more sustainable future.

\section{References}

[1] BP-PLC. BP Statistical Review of World Energy. http://www.bp.com/content/dam/bp/pdf/energy-economics/statistical-review-2016/bpstatistical-review-of-world-energy-2016-full-report.pdf; June 2016 [accessed 17 May 2017]

[2] UNDESA, United Nations Department of Economic and Social Affairs. World population projected to reach 9.7 billion by 2050 .

http://www.un.org/en/development/desa/news/population/2015-report.html; 2015. [accessed 5 June 2017]

[3] UNFPA, United Nations Population Fund. World Population Trends. http://www.unfpa.org/world-population-trends; 2017 [accessed 25 May 2017]

[4] Zabel, Graham. Peak People: The Interrelationship between Population Growth and Energy Resources.http://www.resilience.org/stories/2009-04-20/peak-peopleinterrelationship-between-population-growth-and-energy-resources; 2009 [accessed 24 May 2017]

[5] Kannan, N. and Vakeesan, D. Solar energy for future world: A review. Renewable and Sustainable Energy Reviews, 2016. 62:1092-1105.

[6] UNDP, United Nations Development Programme. Human Development Report 2016: Barbados. http://hdr.undp.org/sites/all/themes/hdr_theme/country-notes/BRB.pdf; 2016. [accessed 13 June 2017]

[7] Central Intelligence Agency, CIA. Central American and Caribbean: Barbados. https://www.cia.gov/library/publications/the-world-factbook/geos/bb.html; 2017. [Cited: 2 May 2017]

[8] StatisticsTimes. List of Countries by Population Density. http://statisticstimes.com/population/countries-by-population-density.php; 2015. [accessed 13 June 2017]

[9] Ince, David. Interim Draft of National Energy Policy for Barbados 2017 to 2036. http://www.energy.gov.bb/; 2017. [accessed 29 May 2017]

[10] Commonwealth Secretariat. Energy: the Key to a Cleaner, More Prosperous Caribbean. [ed.] Commonwealth Secretariat. Achieving a Resilient Future for Small States: Caribbean 2050. London: Commonwealth Secretariat, 2016, 73-112. 
[11] Haynes, Bryan A. Overview and Analysis of the Energy Market. http://brea.bb/wpcontent/uploads/2017/03/Overview-and-Analysis-of-the-Energy-Market-BryanHaynes.pdf;16 June 2017 [accessed 29 June 2017]

[12] IMF, International Monetary Fund. IMF Working Paper: Caribbean Energy: Macrorelated Challenges. https://www.imf.org/external/pubs/ft/wp/2016/wp1653.pdf; March 2016. [accessed 4 May 2017]

[13] IPCC, Intergovernmental Panel on Climate Change. Emissions Scenarios. http://www.ipcc.ch/ipccreports/sres/emission/index.php?idp=50; 2017. [accessed 2 March 2017.]

[14] UN-OHRLLS, Office of the High Representative for the Least Developed Countries, Landlocked Developing Countries and Small Island Developing States. Small Island Developing States: Small Islands Big(er) Stakes. http://unohrlls.org/customcontent/uploads/2013/08/SIDS-Small-Islands-Bigger-Stakes.pdf; 2011. [accessed 4 May 2017]

[15] Ernest EY, and Young. Focus on Barbados Budget. http://www.ey.com/Publication/vwLUAssets/EY-barbados-budget-20172018/\$FILE/EY-barbados-budget-2017-2018.pdf; June 2017. [accessed 26 June 2017]

[16] Ochs, Alexander, et al. Caribbean Sustainable Energy Roadmap and Strategy (CSERMS). http://www.worldwatch.org/system/files/C-SERMS_Baseline_10.29.2015.pdf. 2015. [accessed 6 June 2017]

[17] BP-PLC. Renewable energy - 2015 in review. http://www.bp.com/en/global/corporate/energy-economics/statistical-review-of-worldenergy/renewable-energy.html; 2016. [accessed 5 June 2017]

[18] REN21, Renewable Energy Policy Network for the 21st Century. Renewables 2015 Global Status Report. Paris: REN21 Secretariat, 2015.

[19] Kinab, E and Elkhoury, M. Renewable energy use in Lebanon: Barriers and solutions, Renewable and Sustainable Energy Reviews, 2012,16: 4422-4431.

[20] GOB, Government of Barbados. Barbados - Intended National Determined Contribution. http://www4.unfccc.int/ndcregistry/PublishedDocuments/Barbados\%20First/Barbados\% 20INDC\%20FINAL\%20September\%20\%2028,\%202015.pdf; 2015. [accessed 2 February 2017]

[21] GOB \& IDB, Government of Barbados, The Inter-American Development Bank. Sustainable Energy Framework for Barbados. [https://bajan.files.wordpress.com/2011/07/barbados-sustainable-energy-framework-voli.pdf; June 2010. [accessed 1 November 2016]

[22] Rogers, T. Development of innovation systems for small island states: A functional analysis of the Barbados solar water heater industry. Energy for Sustainable Development, 2016, 31: 143-151.

[23] Wolf, Franziska, et al.Energy access and security strategies in Small Island Developing States. Energy Policy, 2016, 98: 663-673.

[24] WMO, World Meteorological Organization. Small Island Developing States and Member Island Territories. https://public.wmo.int/en/programmes/programme-wmosmall-island-developing-states-and-member-island-territories. 2017. [accessed 17 May 2017.]

[25] GE, General Electric. Three Reasons Why Renewable Energy Is So Important To The Power Industry. https://www.gepowerconversion.com/inspire/three-reasons-whyrenewable-energy-so-important-power-industry. 2015. [accessed 25 May 2017]

[26] Lancaster, A. M. S. N. Caribbean Region Report: The Caribbean An Emerging Framework for Renewable Energy in The CARICOM Region. http://webcache.googleusercontent.com/search?q=cache:pkq3gHJZe68J: 
www.iucnael.org/en/documents/1148-barbados/file+\&cd=1\&hl=en\&ct=clnk\&gl=uk; 2014. [assessed 29 June 2017.]

[27] Ince, D, Vredenburg, H and Liu, X. Drivers and inhibitors of renewable energy: A qualitative and quantitative study of the Caribbean. Energy Policy, 2016, 98: 700-712.

[28] Shirley, R and Kammen, D. Renewable energy sector development in the Caribbean: Current trends and lessons from history. Energy Policy, 2013, 57: 244-252.

[29] Industries, Ministry of Energy and Energy. Oil and Gas Industry. http://www.energy.gov.tt/our-business/oil-and-gas-industry/;2017. [accessed 17 May 17]

[30] IPCC, Intergovernmental Panel on Climate Change. IPCC Fourth Assessment Report: Climate Change 2007.

https://www.ipcc.ch/publications_and_data/ar4/syr/en/spms2.html; 2007. [accessed 24 May 2017]

[31] UN, United Nations. UN and Climate Change. http://www.un.org/climatechange/thescience/;2017. [accessed 24 May 2017]

[32] Dornan, M and Shah, K. U. Energy Policy, aid and the development of renewable resources in Small Island Developing States. Energy Policy 2016, 98: 759-767.

[33] UN-OHRLLS, Office of the High Representative for the Least Developed Countries, Landlocked Developing Countries and Small Island Developing States. Small Island Developing States: Small Islands Big(er) Stakes. http://unohrlls.org/customcontent/uploads/2013/08/SIDS-Small-Islands-Bigger-Stakes.pdf; 2011. [accessed 4 May 2017]

[34] The World Bank. Unlocking the Caribbean's energy potential. http://www.worldbank.org/en/news/opinion/2015/01/31/unlocking-the-caribbeansenergy-potential; 2015. [accessed 24 May 2017.]

[35] CARICOM, Caribbean Community. CARICOM. http://caricom.org/about-caricom/whowe-are. 2017. [accessed 8 June 2017.]

[36] CARICOM Energy Policy. http://cms2.caricom.org/documents/10862caricom_energy_policy.pdf; March 2013. [accessed 8 June 2017.]

[37] REEP, Renewable Energy and Energy Efficiency Partnership. Barbados. https://www.reeep.org/barbados-2014; 2014. [accessed 4 May 2017]

[38] Division of Energy. About the Energy Division: Overview. http://www.energy.gov.bb/web/about-the-energy-division; 2017. [accessed 4 May 2017]

[39] NREL, National Renewable Energy Laboratory. Energy Transition Initiative: Energy Snapshot Barbados. http://www.nrel.gov/docs/fy15osti/64118.pdf. June 2015. [accessed 29 May 2017]

[40] Emera Caribbean. Annual Report. http://www.emeracaribbean.com/siteemera/media/EmeraCaribbean/2015\%20Emera\%20Caribbean\%20Inc.pdf; 2014. [accessed 15 November 2016]

[41] Economics, Trading. Barbados Credit Rating. https://tradingeconomics.com/barbados/rating; 2017. [accessed 2 July 2017]

[42] Rogers, Aidan J. Getting the Policy Right. http://brea.bb/wpcontent/uploads/2017/03/BREA-Stakeholder-Consultation-Meeting-Getting-the-PolicyRight-A.Rogers.pdf. June 2017. [accessed 3 July 2017.]

[43] Ernest EY, and Young. Focus on Barbados Budget. http://www.ey.com/Publication/vwLUAssets/EY-barbados-budget-20162017/\$FILE/EY-barbados-budget-2016-2017.pdf; 2016. [accessed 3 July 2017]

[44] Ministry of Energy and the Environment. The National Energy Policy of Barbados. https://www.scribd.com/document/18190048/Barbados-National-Energy-Policy-DraftDecember-2006; 2006. [accessed 3 June 2017] 
[45] UNFCCC, The United Nations Framework Convention on Climate Change. Barbados submits its Climate Action Plan ahead of the 2015 Paris Agreement.

http://newsroom.unfccc.int/unfccc-newsroom/barbados-submits-its-climate-action-planahead-of-2015-paris-agreement/; 2015. [accessed 2 February 2017]

[46] Headley, Oliver St.C. Solar Thermal Applications in the West Indies. Renewable Energy, 1998, 15: 257-263.

[47] Moseley, L and Headley, Oliver StC.Medium scale photovoltaic applications for Barbados.Renewable Energy, 1999, 17: 1-7.

[48] CREDP/GTZ, Caribbean Renewable Energy Development Programme and German Technical Cooperation. Analysis of the Potential Solar Energy Market in the Caribbean. http://www.solarthermalworld.org/content/analysis-potential-solar-energy-marketcaribbean-2010; July 2010. [accessed 7 June 2017]

[49] BL\&P, Barbados Light and Power. Renewable Energy Rider. https://www.blpc.com.bb/cus-req/cus-servicerider.html; 2015. [accessed 4 June 2017]

[50] Harewood, Robert. RER Growth at the end of 2016. Personal communication, 2016.

[51] The Mills Archive Trust. Caribbean Sugar Mills. https://millsarchive.org/explore/features-and-articles/entry/111785/mildred-cooksoncollection/6044; 2010. [accessed 1 June 2017]

[52] Solar Dynamics. Solar Dynamics- About Use. http://www.solardynamicslimited.com/about-us/; 2017. [accessed 29 May 2017]

[53] Husbands, James. The History and Development of the Solar Hot Water Industry in Barbados. http://solardynamicslimited.com/wp-content/uploads/2016/10/Histor-SolarWater-Heating-Industry-Barbados.pdf.; 2016. [accessed 29 May 2017]

[54] Garder, Devon. Development and Implementation of a strategy for the promotion of Solar Water Heating in CARICOM countries. http://cipore.org/wpcontent/uploads/downloads/2013/02/Final-Report-Solar-Water-Heating-Strategy-CCCountries-Devon-Gardner.pdf.;December 2011. [accessed 29 May 2017]

[55] Barbados Statistical Service. The 2010 Population and Housing Census. http://www.barstats.gov.bb/files/documents/PHC_2010_Census_Volume_1.pdf.; September 2013. [accessed 29 May 2017]

[56] Mauthner, Franz, Weiss, Werner and Spork-Dur, Monika. Solar Heat Worldwide: Markets and Contribution to the Energy Supply 2013. https://www.ieashc.org/data/sites/1/publications/Solar-Heat-Worldwide-2015.pdf.; June 2015. [accessed 29 May 2017]

[57] Nuber, Dr Dirk. Chief Executive Officer of Viking Heat Engines, Personal Communication. 29 March 2017.

[58] Berg, B. L., Qualitative research methods for the social sciences, $7^{\text {th }}$.Edition, Pearson Education Allyn and Bacon, Boston, 2009, Ch 4:101-109.

[59] Alshenqeeti, H. Interviewing as a Data Collection Method: A Critical Review.English Linguistics Research, 2014,3.

[60] Dillman, Don A, et al. Internet, Phone, Mail, and Mixed-Mode Surveys- The Tailored Design Method. 4th. Hoboken: John Wiley \& Sons, Inc, 2014.

[61] Da Silva, Izael P. The four barriers for the diffusion of solar energy technologies in Africa: Trends in Kenya. http://africapolicyreview.com/analysis/four-barriers-diffusionsolar-energy-technologies-africa-trends-kenya/;2016. [accessed 7 June 2017.]

[62] Karakaya, E and Sriwannawit, P. Barriers to the adoption of photovoltaic systems: The state of the art. Renewable and Sustainable Energy Reviews 2015, 49: 60-66.

[63] Mondal, A.H, Kamp, L M and Pachova, N I. Drivers, barriers and strategies for implementation of renewable energy technologies in rural areas in Bangladesh- An innovative system analysis. Energy policy, 2010, 38: 4626-4634. 
[64] Timilsina, G R and Shah, K U.Filling the gaps: Policy supports and interventions for scaling renewable energy development in Small Island Developing States. Energy Policy, 2016, 98: 653-662.

[65]Zuboy, J and Margolis, R. Nontechnical Barriers to Solar Energy Use: Review of Recent Literaturehttp://www.solaripedia.com/files/1097.pdf.; September 2006. [accessed 1 November 2016]

[66] Philibert, C. Barriers to Technology Diffusion: The Case of Solar Thermal Technologies. https://www.iea.org/publications/freepublications/publication/solar_thermal.pdf.; October 2006. [accessed 6 December 2016]

[67] Eleftheriadis, I M and Anagnostopoulou, E G. Identifying barriers in the diffusion of renewable energy sources. Energy Policy, 2015, 80; 153-164.

[68]Zhang, X, Shen, Land Chan, S Y.The diffusion of solar energy use in HK: What are the barriers? Energy Policy, 2012, 41; 241-249.

[69] Niles, K and Lloyd, B. Small Island Developing (SIDS) \& energy aid: Impacts on the energy sector in the Caribbean and the Pacific. 5, Energy for Sustainable Development, 2013, 17: 521-530.

[70] Gabriel, Cle-Anne, et al. How do developing country constraints affect renewable energy entrepreneurs, Energy for Sustainable Development, 2016. 35: 52-66.

[71] OFGEM, Office of Gas and Electricity Markets. Feed-in-Tariffs (FiT) rates. https://www.ofgem.gov.uk/environmental-programmes/fit/fit-tariff-rates; 2017. [accessed 10 July 2017]

[72] BREA, Barbados Renewable Energy Association. Consumer Guide: Solar PV. http://brea.bb/wp-content/uploads/2016/06/BREA-Solar-guide.pdf.; 2016. [accessed 3 November 2016]

[73] Clarke, M. Barriers to the Uptake of Solar Energy in Barbados.Personal Communication, 4 April 2017.

[74] Mangold, W G and Faulds, D J.Social media: The new hybrid element of the promotion mix. Business Horizons, 2009, 52: 357-365.

[75] Ochs, Alexander, et al. Worldwatch Report-Sustainable Energy Roadmaps: Guiding the Global Shift to Domestic Renewables. http://www.worldwatch.org/system/files/EWP187_0.pdf.; 2012. [accessed 2 July 2017]

[76] APM, Association for Project Management. 10 key principles of stakeholder engagement. https://www.apm.org.uk/resources/find-a-resource/stakeholderengagement/key-principles/; 2017. [accessed 7 July 2017]

[77] Diaz, P, Adler, C and Patt, A.Do stakeholders' perspectives on renewable energy infrastructure pose a risk to energy policy implementation? A case of a hydropower plant in Switzerland. Energy Policy, 2017, 108: 21-28.

[78] Gustafsson, Sara, Ivner, Jenny and Palm, Jenny Management and stakeholder participation in local strategic energy planning - Examples from Sweden. Journal of Cleaner Production, 2015, 98: 205-212.

[79] BREA, Barbados Renewable Energy Association. BREA's statement on 2017 Financial Statement and Budgetary Proposals. http://brea.bb/breas-statement-on-2017-financialstatement-and-budgetary-proposals/; 2017. [accessed 3 July 2017]

[80] SunPower. Energy Savings. http://www.sunpowr.com/thefacts.html.; 2017. [accessed 10 July 2017]

[81] Akinyele, D., Belikov, J and Levron, Y. Challenges of Microgrids in Remote Communities: A STEEP Model Application. Energies, 2018, 11: 432; doi:10.3390/en11020432 